\title{
Institutions and Wage Determination: a Multi-Country Approach*
}

\author{
Luca Nunziata ${ }^{\dagger}$
}

January 31, 2002

\begin{abstract}
We present an empirical analysis of the determinants of labour cost in OECD countries, with particular reference to the impact of labour market institutions from 1960 to 1994. The main contribution of the paper is to show that labour market regulations can explain a large part of labour cost rise in OECD countries in the last decades once we control for productivity. These results are consistent with the findings of a companion paper (Nickell et al., 2001) where the effects of institutions on unemployment are examined. The model controls for macroeconomic shocks, and include the possibility of interactions among institutions. We present also a discussion of the potential problems encountered when estimating a macro pooled model like ours. We focus, among other things, on the hypothesis of poolability and on the cointegration properties of the model, suggesting a two way fixed effects specification in GLS form that corrects for heteroskedasticity and serial correlation. The explanatory power of the model is finally tested by means of a series of by country dynamic simulations.
\end{abstract}

Theme: Labour Cost

Keywords: Labour Cost, Wage, Labour Market Institutions, Unemployment, MultiCountry Regression

JEL-Code: E24, J31, J51.

\footnotetext{
${ }^{*}$ I wish to thank Stephen Nickell for his invaluable comments and insights, John Muellbauer and Stephen Bond for their very helpful remarks. The usual disclaimer applies.

${ }^{\dagger}$ Department of Economics, University of Bologna and Nuffield College, University of Oxford. Email for correspondence: luca.nunziata@nuffield.ox.ac.uk .
} 


\section{Introduction}

One of the most challenging tasks for contemporary macroeconomics is the construction of robust empirical tests of the explanatory power of alternative theories of unemployment. Recent contributions by Nickell (1997), Elmeskov et al. (1998), Belot and van Ours (2000), Blanchard and Wolfers (2000) and Bertola et al. (2001) have shed some light on the causal relationship that links institutional factors and macroeconomic shocks with the rise and the persistence of high unemployment levels in most of the OECD countries. However we still lack of an empirical account of the way labour market institutions affect unemployment levels through their impact on wage determination. As we will see below, an important part of the explanation of the impact of labour market institutions on unemployment can be derived by the role played by these institutions in the wage determination process. If institutions do matter in the explanation of OECD unemployment patterns, then we should be able to estimate a significant impact on wages as well. Moreover, even if some institutions do not affect unemployment directly, exerting pressure on wages, but through their impact on the matching process of the unemployed to available job vacancies, they should have a significant impact on wages as well through the movements in equilibrium labour demand. The unemployment and the wage models are intimately connected and should yield coherent results.

This work and the companion paper Nickell et al. (2001) propose an empirical investigation of the combined effects of wage pressure factors and labour market institutions on unemployment rates and labour cost. Our aim is to produce an empirical investigation of the time series properties of OECD unemployment and to yield some insight on the far from homogeneous experience of each single country. This paper concentrates on labour cost determination in OECD countries, while Nickell et al. present a broader picture, including an account of unemployment patterns and the Beveridge Curve in those countries.

The structure of the paper is the following: the next section contains a concise theoretical introduction, section three presents a model of labour cost determination and a brief description of what we intend for labour market institutions. Section four includes a brief overview of the existing multi-country models of labour cost determination. Sections five, six and seven present the empirical analysis, including some comments on the specification of the econometric model. Section eight contains some final remarks ${ }^{1}$.

\section{Unemployment and Labour Cost Determination}

Our theoretical background is Nickell (1998). According to his simple model, the wage setting framework is described by the equation:

$$
w=\theta_{1} p^{e}+\left(1-\theta_{1}\right) p-\theta_{2} u-\theta_{3} \Delta u+z_{w}
$$

where wages are assumed to be set as a mark-up on averaged actual and expected prices, and $z_{w}$ indicates the vector of all exogenous wage pressure factors. The extent of

\footnotetext{
${ }^{1}$ Note that in what follows we use indifferently the term wage and labour cost, intending the real product wage (labour costs per employee normalised on the output price). This includes non wage costs such as employers' contributions.
} 
the mark up is influenced by the state of the labour market, represented by the unemployment rate $u$ (here in logs) and the growth rate of unemployment $\Delta u$.

Assuming mark-up price setting behaviour for firms, a standard production function and a mix of anticipated and unanticipated shocks on demand, price, and wages, this stylized model yields the following reduced unemployment equation:

$$
u=\phi_{1} u_{-1}+\phi_{2}\left(\bar{z}_{p}+\bar{z}_{w}\right)-\phi_{2}\left(\epsilon_{n}+\lambda \epsilon_{r}\right)+\phi_{3}\left(\epsilon_{p}+\epsilon_{w}\right)
$$

where $\left(\bar{z}_{w}, \bar{z}_{p}\right)$ represent anticipated autonomous shifts in wages and prices respectively, $\left(\epsilon_{w}, \epsilon_{p}\right)$ are unanticipated shifts in the same variables, and $\left(\epsilon_{n}, \epsilon_{r}\right)$ are unanticipated nominal and real demand shocks. In addition, we have that $\phi_{1}=\theta_{3} / \theta$ and $\phi_{2}=\theta^{-1}$, with $\theta=\left(\theta_{2}+\theta_{3}\right)$. The assumption of rational expectations rules out any effect of anticipated demand shocks on unemployment.

A few points can be drawn from this simple setting:

- There exists a negative long run relationship between unemployment and real demand factors. This relationship is the obvious consequence of whichever specification we may assume for the production function, since labour is a fundamental input for production.

- The relationship between unemployment and wage and price pressure factors $\left(\bar{z}_{w}, \bar{z}_{p}\right)$ depends on the impact of unemployment on wages, i.e. on the coefficient $\theta_{2}$.

(i) If the unemployment level does not affect wages, i.e. if $\theta_{2}=0$, then $\phi_{1}=1$ and according to equation (2) unemployment will follow a random walk process. In this case its actual level will depend on the history of past shocks, and any unemployment level will be compatible with stable inflation.

(ii) If unemployment significantly affects wages, i.e. if $\theta_{2}>0$, then the effect of past shocks falls with time at a rate which increases with $\theta_{2}$. Most importantly, there exists a level of unemployment $u^{*}=\frac{1}{\theta_{2}}\left(\bar{z}_{w}+\bar{z}_{p}\right)$ such that if unemployment is consistently lower than $u^{*}$ there is a tendency for inflation to grow. The unemployment level $u^{*}$ is determined by wage and price pressure factors $\left(\bar{z}_{w}, \bar{z}_{p}\right)$.

The intuition underlying last point is that autonomous changes in unemployment could be offset by labour market forces if higher unemployment triggers a reduction in wages. If this is the case, unemployment will depend on wage pressure institutions. If this is not the case, we expect unemployment to be fully persistent (i.e. it will follow an $I(1)$ process).

The analysis of equation (1) is therefore a crucial step in order to understand the sources of OECD unemployment. Consequently, the objectives of the paper are the following:

1. to analyse the impact of unemployment on wages;

2. to investigate the impact of labour market institutions on wages;

3. to investigate the coherence of the wage model with the analogous model of unemployment contained in the companion paper Nickell et al. (2001). 
This paper concentrates on the estimation of a labour cost equation while Nickell et al. (2001) provides an extensive account of the unemployment model based on the same criteria. The theoretical and empirical relationships between the two analysis have been briefly discussed here. A broader discussion can be found in the companion paper.

\section{A Model of Labour Cost Determination}

Equation (1) may be written as:

$$
w-p=-\theta_{2} u-\theta_{3} \Delta u+z_{w}-\theta_{1}\left(p-p^{e}\right)
$$

where the term $\theta_{1}\left(p-p^{e}\right)$ reflects macro shocks.

If we want to generalise this simple model we have to allow wages to be ceteribus paribus anchored to productivity in equilibrium. In addition, there are empirical and theoretical reasons to expect some form of persistence in wage dynamics ${ }^{2}$. A general dynamic reduced form, allowing for a positive productivity trend $\pi$ and endogenous persistence, is therefore:

$$
w_{t}-p_{t}=\beta_{0}+\beta_{1}\left(w_{t-1}-p_{t-1}\right)-\beta_{2} u_{t}-\beta_{3} \Delta u_{t}+\beta_{4} \pi_{t}+\gamma^{\prime} \overline{\mathbf{z}}_{w, t}+\boldsymbol{\vartheta}^{\prime} \mathbf{s}_{t}
$$

where the same notation used above applies here, with $\overline{\mathbf{z}}_{w}$ being the vector of wage pressure factors, and $\mathbf{s}$ a vector of nominal and real shocks.

According to equation (4) the log real wage level depends respectively on last period's value, labour market conditions represented by the level and change in unemployment, i.e. $u_{t}$ and $\Delta u_{t}$, the productivity trend $\pi_{t}$, wage pressure factors $\overline{\mathbf{z}}_{w}$, and a set of macro shocks $\mathbf{s}_{t}$. Given the peculiar nature of our sample period, starting in 1960 when unemployment was virtually zero in some countries, in what follows we do not impose unemployment to be in $\operatorname{logs}^{3}$, since we would introduce spurious variability in the series ${ }^{4}$.

The vector of wage pressure factors $\overline{\mathbf{z}}_{w}$ includes the set of all labour market institutions that influence the matching process of unemployed individuals to available job vacancies, or directly raise wages in presence of excess labour supply, or both. In any case they will impact wages and unemployment in the same direction, since labour demand, which is negatively related to wages, will move in the opposite direction of unemployment in equilibrium.

The institutions can be broadly classified into wage bargaining institutions, institutions related to unemployment benefit provision, employment protection regulations and labour taxation. The empirical counterpart of each institutional dimension is represented by an indicator provided by the Labour Market Institutions Database (LMID), assem-

\footnotetext{
${ }^{2}$ This can depend on various factors, the most obvious being a certain degree of persistence of the impact of macro shocks. Moreover, in the presence of staggered wage adjustment in most countries, only a fraction of total contracts will be renewed every period, with the a resulting strong autocorrelation in the average wage.

${ }^{3}$ For example, Germany, New Zealand and Switzerland.

${ }^{4}$ For example, in log form, the rise in unemployment in Switzerland from 1960-64 to $1996-99$ (0.2\% to $3.7 \%$ ) has a negative impact on wages which is nearly 300 percent larger than that in Italy where unemployment rose from $3.5 \%$ to $10 \%$. This differential seems somewhat implausible.
} 
bled by Nickell and Nunziata from different sources, and extensively described in the data appendix of this paper ${ }^{5}$.

The institutions having a direct impact on the wage determination process are the trade union bargaining power and the degree of coordination in wage bargaining. The latter represents the extent to which parties to wage bargaining are able to take account of the macroeconomic consequences of their decisions. Union power consists instead of two major dimensions that are the proportion of employees covered by collective agreements (union coverage) and the union membership rate among active workers (union density). Unfortunately, we can only estimate the wage impact of union density since the data on union coverage is available for a very limited number of years ${ }^{6}$. As suggested by previous analysis, we expect a positive impact of union bargaining power on wages, although the effect is likely to be offset if bargaining is highly coordinated ${ }^{7}$.

As regards unemployment benefits, a generous system has a direct negative influence on the willingness of the unemployed to undertake a vacant job. Both the amount and the time duration of the monetary transfer to unemployed individuals may matter in this respect. The former is summarised by the benefit replacement rate, i.e. the ratio of the average unemployment benefit on the average salary, aggregated over family types ${ }^{8}$. The attitude of the unemployed can also be influenced by the returns on non human wealth which may be increasing in the real interest rate . $^{9}$

Employment protection regulations are by definition the set of rules and procedures governing the treatment of dismissals of employed workers. Much of the economic literature insists on the negative impact of these regulations on the employment dynamics ${ }^{10}$. In addition, they raise the bargaining power of insiders, inducing an upward pressure on bargained wages. However, it is not clear if these regulations exert an effect as significant on the employment level (and therefore on unemployment) in equilibrium. A series of conflicting effects are involved here: inflows into unemployment are reduced by higher protection, while the effect on outflows from unemployment is unclear. Firms may be more cautious about hiring new staff, but the quality of the personnel may be improved by a reduction in the trial-and-error recruitment procedures ${ }^{11}$.

Finally, by labour taxation we mean the tax wedge between the real product wage paid by the employer and the real consumption wage received by the employee ${ }^{12}$. This consists of the sum of the payroll tax rate, the income tax rate and the consumption tax rate. The question here is how much part of the increase in the tax wedge is born by the

\footnotetext{
${ }^{5}$ See also Nickell and Nunziata (2001), the description in Nunziata (2001) and the general discussion in Nickell et al. (2001). A general survey on labour market institutions is provided by Nickell and Layard (1999) while some previous discussions can be found in Layard et al.(1991), Bean (1994) and Nickell (1997).

${ }^{6}$ See Nickell et al. (2001) for a summary picture of the OECD union coverage patterns.

${ }^{7}$ See Nickell and Layard (1999) and Boeri et al. (2001).

${ }^{8} \mathrm{No}$ long and comprehensive series on the coverage or on the strictness of the benefit provision system are available for all the countries. Nevertheless, these factors may be of a certain importance in explaining the experience of countries with generous benefits. It is the case of Denmark, where, according to the Ministry of Labour, the implementation of a tighter enforcement system in the 1990s was one of the main causes behind the large reduction in unemployment unaccompanied by any inflationary pressure (see Danish Ministry of Finance, 1999, Chapter 2).

${ }^{9}$ See Phelps (1994) for a broader discussion.

${ }^{10}$ See, for example, Bentolila and Bertola (1990), Nickell and Nunziata (2000) and Nunziata (2001).

${ }^{11}$ See Daniel and Stilgoe (1978) and Evans et al. (1985) for a discussion on the UK.

${ }^{12}$ The former is normalised on the GDP deflator, while the latter uses the consumer price index.
} 
employers or shifted to the employees through a reduction in the after-tax consumption wage. In the first case both wages and unemployment increase, while in the second case labour costs and unemployment are unaffected. The extent to which wages and unemployment respond to changes in the tax wedge tells us which direction prevails. A similar real wage resistance effect can be generated by an adverse shift in the terms of trade or by an unexpected fall in trend productivity growth.

\section{Some Previous Multi-Country Models}

Most of the existing empirical cross country literature on labour cost determination concentrates on the effects of taxation on wages. This is found to be shaped by the institutional configuration of the labour market, however this is defined ${ }^{13}$.

Newell and Symons (1985) use marginal tax data in a simple cross country regression setting, finding a significant negative correlation between marginal tax rates and technical progress, real product wages, investment and labour force participation, and a positive correlation with the unemployment rate. The econometric analysis however is not robust, since the authors do not control for country effects.

Alesina and Perotti (1997) propose a more sophisticated panel analysis of 14 OECD countries, for the period 1965 to $1990^{14}$. They regress unit labour costs on labour tax, a centralization in wage bargaining dummy, total factor productivity and some other controls. The countries are divided into three groups according to their degree of centralization in wage bargaining, and the labour tax variable is interacted with the relative three indicator variables. The empirical evidence produced by the authors supports the view that an increase in labour taxation induces a labour cost increase in countries with an intermediate degree of bargaining centralization ${ }^{15}$. According to the authors, this result suggests that the relationship between taxation and wages is hump shaped. In other words, highly decentralized countries are characterized by lower distortions while if bargaining is highly centralized then unions internalize the welfare improvements associated with higher tax pressure, demanding lower pay increases ${ }^{16}$.

However, given that all the variables included in the regressions are in log difference the model implies that a 10 percent rise in taxes from the average value in 1960-1990 induces a somewhat implausible 27 percent increase in unit labour costs in the intermediate countries. In addition consumption taxes are omitted from the labour tax variable, which is defined as the sum of direct taxes paid by households, social security taxes paid by employers and employees and payroll taxes as shares of GDP. This omission should be tested, since we should expect that a switch from income taxation to consumption taxation

\footnotetext{
${ }^{13}$ The empirical literature on wage determination is immense. A number of other relevant contributions are not mentioned here because of the different emphasis or methodology. See, for example, the macroeconomic papers of Alogoskoufis and Manning (1988) and Bean et al. (1986), as well as the literature on wage curves originated by Blanchflower and Oswald $(1990,1994)$ that concentrates especially on micro data.

${ }^{14}$ The countries in the sample are Australia, Belgium, Canada, Denmark, Finland, France, Germany, Italy, Japan, Netherlands, Norway, Sweden, United Kingdom and United States. The base equations include country and year effects.

${ }^{15}$ The countries belonging to the intermediate bargaining centralization group are Germany, Netherlands and Belgium.

${ }^{16}$ See Calmfors and Driffill (1988) and Freeman (1988) for evidence.
} 
would not change wage earners real income ${ }^{17}$. Moreover, the authors' assumption implies, quite implausibly, that by simply replacing payroll and income taxes by consumption taxes, we can reduce labour costs by a huge amount, thereby generating a huge reduction in unemployment.

The main concern about the model is however that labour market institutions are taken into account simply dividing the countries into three groups, on the basis of one dimension only, namely bargaining centralization. In fact, several other features of labour market institutions are likely to be crucial in a model of labour cost. This approach also fails to consider the historical evolution of the characteristics of the bargaining process in each country. The changes can be relevant for some countries and could affect the country classification proposed by the authors. As an example, looking at the time series for coordination used in this paper, we see a 25 percent fall in coordination for Sweden from 1980 to 1995 and a 66 percent raise in Italy from 1990 to 1995.

Daveri and Tabellini (2000) follow a similar approach in a study of the effects of taxation on unemployment and growth on a group of 14 OECD countries ${ }^{18}$. The claim of the paper is that higher taxation is correlated with greater labour costs and therefore with higher unemployment and a lower rate of growth. Although the theoretical arguments of the authors are in some way different from Alesina and Perotti, the conclusions are comparable. The analysis is constructed using five years averaged data in order to remove cyclical fluctuations, and the tax data is constructed using the methodology suggested by Mendoza, Razin and Tesar (1994). The countries are divided into three groups according to the characteristics of their bargaining system, where the composition of each group is different from the one adopted by Alesina and Perotti, possibly because the authors do not consider only centralization as a subdivision criteria, but other bargaining dimensions too $^{19}$. The estimation results indicate that taxation has a positive significant impact on unemployment in the countries belonging to the intermediate group, namely continental Europe plus Australia. There is also a positive effect for Canada, US, Japan and Thatcher UK, but weaker. Regarding labour costs, the authors estimate two alternative models, using respectively data on the growth rate of gross real earnings in manufacturing, and the growth rate of net real wages of the average manufacturing worker. The reported 2SLS coefficients in the first more robust case indicate that higher taxation is correlated with higher labour costs in continental Europe and Australia, so that a unit change in the average tax is translated into a 0.49 percent increase of gross real wage.

Being the methodology used by Daveri and Tabellini quite similar to the one adopted by Alesina and Perotti, similar comments apply here. In this case too, the tax data does not include consumption taxation, and the unemployment regressions are quite bald, with very few regressors. In addition, the composition of each country group, according to the institutional framework governing wage bargaining, suffers from a certain degree of subjectivity. Indeed, the choice of including one country in one group instead of another ultimately responds to the criteria implied by the authors. Even if we were to rule out subjectivity, there seems to be no reason why we should stick to one rule only. The subdivision criteria can be various and contradictory, with a likely relevant impact on the estimation results.

\footnotetext{
${ }^{17}$ See Nickell and Layard (1999).

${ }^{18}$ With respect to Alesina and Perotti, they include Spain in the sample and exclude Danemark.

${ }^{19}$ These are union density, union coverage and coordination.
} 
Our model intends to respond to these problems and limitations. In what follows we provide an empirical test of the impact of institutions on labour cost determination in OECD countries, together with an investigation of the role played by labour market forces.

\section{The Econometric Model}

We estimate a general version of equation (4) on a sample of 20 OECD countries observed from 1960 to 1994. The baseline specification of the empirical model is the following:

$w_{i t}-p_{i t}=\beta_{0}+\beta_{1} w_{i t-1}-\beta_{2} U_{i t}-\beta_{3} \Delta U_{i t}+\beta_{4} \pi_{i t}+\gamma^{\prime} \overline{\mathbf{z}}_{w, i t}+\boldsymbol{\lambda}^{\prime} \mathbf{h}_{i t}+\boldsymbol{\vartheta}^{\prime} \mathbf{s}_{i t}+\phi_{i} t_{i}+\mu_{i}+\lambda_{t}+\varepsilon_{i t}$

where the same notation used above applies here with $w_{i t}-p_{i t}$ being the real unit labour cost (i.e. real unit wages, salaries and social security contributions paid by resident producers), $U$ the unemployment rate (that we do not impose to be in logs), $\Delta U$ the difference in the unemployment rate, $\pi$ the productivity trend, $\overline{\mathbf{z}}_{w}$ a vector of labour market institutions, $\mathbf{h}$ a vector of interactions among institutions and other regressors, $\mathbf{s}$ a vector of macroeconomic shocks, $t_{i}$ a country specific time trend, $\mu_{i}$ a fixed country effect, $v_{t}$ a year dummy and $\varepsilon_{i t}$ the stochastic residual ${ }^{20}$.

More specifically, the vector of labour institutions includes:

$$
\gamma^{\prime} \overline{\mathbf{z}}_{w, i t}=\gamma_{1} E P_{i t}+\gamma_{2} B R R_{i t}+\gamma_{3} \Delta U D_{i t}+\gamma_{4} C O_{i t}+\gamma_{5} T W_{i t}
$$

where $E P_{i t}$ is employment protection, $B R R_{i t}$ is the unemployment benefit replacement rate, $U D_{i t}$ is net union density, $C O_{i t}$ is bargaining coordination and $T W_{i t}$ is the tax wedge, i.e. direct + indirect + payroll tax rate.

The vector of interactions in the baseline model has the following form:

$$
\lambda^{\prime} \mathbf{h}_{i t}=\lambda_{1} U R C O+\lambda_{2} U R B R R_{i t}+\lambda_{3} U R U D_{i t}+\lambda_{4} T W C O_{i t}
$$

where each element, denoted with obvious notation, is expressed as interaction between deviations from the world average $\bar{\xi}$, i.e. :

$$
\operatorname{Var} X \operatorname{Var} Y_{i t}=\left\{\operatorname{Var} X_{i t}-\bar{\xi}_{\operatorname{Var} X}\right\} \cdot\left\{\operatorname{Var} Y_{i t}-\bar{\xi}_{\operatorname{Var} Y}\right\} .
$$

Expressing the interactions in this way allows us to read the coefficient of each institution in levels as the coefficient of the "average" country, i.e. of the hypothetical country characterized by the average level of that specific institutional indicator.

The vector of controls for macroeconomic shocks contains the following elements:

$$
\boldsymbol{\vartheta}^{\prime} \mathbf{s}_{i t}=\vartheta_{1} D 2 T F P_{i t}+\vartheta_{2} T T S F C_{i t}
$$

where $D 2 T F P$ is a total factor productivity shock, calculated as the acceleration in productivity, $\triangle^{2} T F P$, and TTSFC is a terms of trade $\operatorname{shock}^{21}$.

\footnotetext{
${ }^{20}$ See the appendix for data definitions and sources.

${ }^{21}$ This is calculated as $\left(\frac{\text { imports }}{G D P}\right) \Delta \log \left(\frac{P_{\text {import }}}{P_{G D P}}\right)$ where $P_{\text {import }}$ is the imports deflator and $P_{G D P}$ is the GDP deflator at factor cost.
} 


\begin{tabular}{lccc}
\hline \hline & RZB Test & RZB Test & Interactions Test \\
\hline \hline Statistic & $\chi_{(171)}^{2}=99.76$ & $F_{(171,392)}=94.86$ & $\chi_{(126)}^{2}=525.01$ \\
P-value & 0.99 & 0.00 & 0.00 \\
\hline Regressors & Institutions and shocks & Institutions and shocks & Institutions and shocks \\
\hline \hline
\end{tabular}

Table 1: Poolability Tests

We adopt a GLS fixed effect estimator, in order to control for country unobservables and to correct for heteroskedasticity across countries as well as residual serial correlation $^{22}$. The time dummies capture instead the contemporaneous correlations across countries. Next section introduces some specification and diagnostic tests that justify the adoption of a GLS fixed effect estimator, discussing the implications and potential problems of this choice. The following sections present the estimations results and some dynamic simulations of the baseline model.

\section{Specification and Diagnostic Tests}

\subsection{Poolability of the data}

When estimating a multi-country equation like in our case, the hypothesis of homogeneous coefficients has to be tested. This is especially relevant in a dynamic setting since, under the assumption of a random coefficient model ${ }^{23}$, if parameter heterogeneity is ignored, the pooled estimator is inconsistent even when $T \rightarrow \infty$, as shown by Pesaran and Smith (1995). We perform the poolability test suggested by Roy (1957), Zellner (1962) and Baltagi (1995) (RZB test) that requires the estimation of the model under the restriction of common slopes across countries, as well as allowing heterogeneous slopes. This test is a generalization of the Chow test for the $N$ linear regressions case, under the general assumption of non spherical disturbances $\varepsilon \sim \mathbf{N}(\mathbf{0}, \boldsymbol{\Omega})$.

Table 1 shows the test statistics for the baseline version of the model, without introducing interactions among institutions. The null hypothesis of poolability is not rejected as shown in the first column of the table. However, this result is not confirmed if we consider the small sample approximation of the distribution of the test, as in column two of the same table.

The tests in column one and two are calculated using a simplified version of the baseline model $^{24}$. The need for this simplification comes from the fact that it is not possible to estimate country specific coefficients for some of the regressors. For example, the coordination variable is constant for some countries over the whole sample period

\footnotetext{
${ }^{22}$ Note that the Balestra-Nerlove random effect specification was always rejected by a standard Hausman test.

${ }^{23} \mathrm{By} \mathrm{RCM}$ it is intended a model such that given the panel specification $y_{i t}=\lambda_{i} y_{i, t-1}+\beta_{i}^{\prime} \mathbf{x}_{i t}+\varepsilon_{i t}$, $i=1,2, \ldots, N, t=1,2, \ldots, T$, the individual coefficients are distributed around a common mean. i.e. $\lambda_{i}=\lambda+\eta_{1 i}$ and $\beta_{i}=\beta+\eta_{2 i}$, with stochastic components having zero means and constant covariances.

${ }^{24}$ This includes labour cost (lagged), unemployment rate, benefit replacement ratio, $\Delta$ union density, tax wedge, total factor productivity shock, term of trade shock and productivity trend.
} 
and we cannot estimate its coefficient in each by country regression ${ }^{25}$. This limitation can be eliminated by calculating an alternative poolability test introducing interactions between the regressors and the country dummies and testing for the joint significance of the interactions. The third column of Table 1 presents the test statistic computed for the baseline labour cost model. Here again the poolability null is rejected.

These tests limit the scope of investigation to the validity of the null hypothesis of homogeneous coefficients for all countries. However, as suggested by Baltagi (1995), the pooled model can yield more efficient estimates at the expenses of bias. McElroy (1977) suggests three tests based on weaker mean square errors (MSE) criteria that do not test the falsity of the poolability hypothesis but allow to choose between the constrained and unconstrained estimator on a pragmatic basis, i.e. on the basis of the trade-off between bias and efficiency.

Under the general assumption of $\varepsilon \sim \mathbf{N}(\mathbf{0}, \boldsymbol{\Omega})$, being $\hat{g}_{G L S}^{*}$ the constrained estimator and $\hat{\delta}_{G L S}^{*}$ the unconstrained estimator, the null hypothesis of the MSE based tests is that $\hat{g}_{G L S}^{*}$ is better than $\hat{\delta}_{G L S}^{*}$ on "pragmatic grounds". Table 2 presents the test statistics calculated for the same model of Table 1 as well as the analytical expression for the null hypothesis. According to the Strong MSE criteria, the pooled estimator is preferable to the unconstrained estimator if $\lambda_{N T} \leq \frac{1}{2}$, with $\lambda_{N T}$ being the non centrality parameter of the test. The first and second Weak MSE tests are constructed such that the pooled estimator is preferable to the unconstrained if the conditions in the last two columns of the table are met. These conditions imply that the unconstrained estimator is characterized by a mean square error which is higher than in the constrained estimator case $\mathrm{e}^{26}$.

These tests suggest that under the second weak MSE criterion the pooled estimator is better than the unconstrained estimator on our data. In other words the pooled model yields more efficient estimates than the by country regressions. Although this result gives us some confidence in pursuing a pooled approach, it is not robust enough to justify a pure coefficient homogeneity framework. Therefore we introduce a set of interactions among institutions and unemployment that allow some institution coefficients to vary across countries and over time. In this way we are also able to control for the institutional complementarity effects suggested by the theory. Our model is therefore semi-pooled in the sense that the institutional coefficients are free to vary across countries and over time, according to the restrictions imposed by the homogeneous coefficients of each interaction. In this respect, in measuring the effects of institutions, we balance the efficiency gains obtained using a pooled empirical approach, with the need to avoid the likely bias produced by a pure homogeneous model ${ }^{27}$.

\footnotetext{
${ }^{25}$ In addition, in the case of New Zealand it is not possible to estimate a complete model since the number of the coefficients is higher than the available observations. This is due to missing observations for the tax wedge in New Zealand before 1975 and after 1986.

${ }^{26}$ Note that in this particular case, the strong MSE and the first weak test almost coincide, being $\phi_{N T}=0.57$.

${ }^{27}$ This approach has also the advantage of simplicity as well as of flexibility, as opposed to more sophisticated methods such as Pesaran and Smith's pooled mean group (PMG) estimator. Indeed, although allowing short run coefficients to vary across countries, the PMG approach imposes long run coefficients to be the same across countries and time. This is a restriction that we do not need to impose when we treat heterogeneity through interactions.
} 


\begin{tabular}{cccc}
\hline \hline & "Strong MSE" Test & "First Weak" MSE Test & "Second Weak" MSE Test \\
\hline \hline Statistic & $\lambda_{N T}=78.05$ & $\lambda_{N T}=78.05$ & $\lambda_{N T}=78.05$ \\
$H_{0}:$ & $\lambda_{N T} \leq \frac{1}{2}$ & $\lambda_{N T} \leq \phi_{N T}=0.57$ & $\lambda_{N T} \leq(N-1) K^{\prime} / 2=85.5$ \\
Pooling is better & no & no & yes \\
\hline \hline
\end{tabular}

Table 2: MSE Poolability Tests

\begin{tabular}{lc}
\hline \hline & Baseline model \\
\hline \hline GH test & $\chi_{(19)}^{2}=4592.66$ \\
P-value & 0.00 \\
\hline \hline
\end{tabular}

Table 3: Test for groupwise heteroskedasticity

\subsection{Nickell Bias in Dynamic Fixed Effect Models}

Nickell (1981) shows that in the AR(1) case the bias of a dynamic fixed effect model is $O(1 / T)$ and therefore becomes less important as $T$ grows. Judson and Owen (1999) test the performance of the fixed effect estimator by means of Monte Carlo simulations, concentrating on panels with typical macroeconomic dimensions, i.e. small $N$ and $T$, with $N \simeq T$. Their analysis suggests that the fixed effect estimator performs as well as or better than many alternatives when $T=30$, i.e. with a $T$ dimension similar to ours.

\subsection{Heteroskedasticity}

The fixed effect specification assumes homoskedasticity. In other words, given a two way error component model as in our case, with $u_{i t}=\mu_{i}+\lambda_{t}+\varepsilon_{i t}$, $\varepsilon_{i t}$ is assumed homoskedastic. If the assumption is not met, then the estimates will still be consistent but inefficient. A groupwise likelihood ratio heteroskedasticity test was performed on the residuals of the baseline model estimated by OLS. The test is chi-squared distributed with $G-1$ degrees of freedom, where $G$ is the number of groups in the sample, 20 countries in our case. Table 3 shows the results of the test, according to which we reject the null hypothesis of homoskedasticity across groups. This suggests the adoption of a feasible fixed effect GLS estimator, with a variance covariance matrix that incorporates heteroskedasticity across countries.

\subsection{Residuals Serial Correlation}

Baltagi and Li (1995) suggest an LM test for serial correlation in fixed effects models. The two versions of the test, presented in Table 4, are calculated assuming two alternative specifications for the error autocorrelation structure, namely $A R(1)$ and $M A(1)$. The asymptotic distribution of the test statistics is calculated for $T$ large. Under both assumptions, the null hypothesis of no serial correlation in the disturbances is rejected. Given the results of the heteroskedasticity and autocorrelation tests, the feasible GLS estimator in this paper is constructed assuming by country groupwise heteroskedasticity and an $\operatorname{AR}(1)$ structure in the disturbances $\varepsilon_{i t}$. 


\begin{tabular}{lc}
\hline \hline & Baseline model \\
\hline \hline$L M$ test, $A R(1)$ & \\
$\varepsilon_{i t}=\rho \varepsilon_{i, t-1}+v_{i t}$ & $\chi_{(1)}^{2}=31.51$ \\
$H_{0}: \rho=0$ & P-value $\simeq 0.000$ \\
$L M_{5}$ test, $M A(1)$ & \\
$\varepsilon_{i t}=v_{i t}+\lambda v_{i, t-1}$ & $N(0,1)=5.61$ \\
$H_{0}: \lambda=0$ & P-value $\simeq 0.000$ \\
\hline \hline
\end{tabular}

Table 4: Tests for serial correlation

\subsection{Overconfidence in GLS Pooled Models}

The adoption of a pooled feasible GLS approach is not exempt from potential problems. Beck and Katz (1995) argue that the application of feasible GLS to time-series crosssectional data can lead to underestimating the coefficients' standard errors. This is due to the large number of parameters that need to be estimated when modelling the variance covariance matrix $\hat{\Omega}$. The matrix $\hat{\Omega}$ should account in principle for country heteroskedasticity, by country autocorrelation as well as contemporaneous correlation across countries. The main problem is generated by the need to estimate the $N \times(N+1) / 2$ time invariant contemporaneous covariances across countries using $N T$ observations. This requires a time dimension $T$ considerably larger than $N$ since the downward bias in the standard errors is larger the closer to zero is $N T-N \times(N+1) / 2$. However, in our case this condition is not needed, since we model contemporaneous cross country correlations through the inclusion of time dummies. This results in a variance covariance matrix $\hat{\Omega}$ with only $N \times 2$ parameters, represented by $N$ variances and $N$ autocorrelations ${ }^{28}$.

\subsection{Unit Roots and Panel Cointegration}

We check for unit roots in each country series using an augmented Dickey Fuller test with trend that is valid in presence of serial correlation of unknown form ${ }^{29}$. The results of the tests are shown in Table 5. As we can see there is a clear evidence of non stationarity for many of the variables. In particular the standardized unemployment rate, employment protection, the benefit replacement ratio, benefit duration, union density, coordination and the tax wedge are non stationary in each country. We therefore need to test for cointegration, and one simple way of doing this is to test for unit roots in the residuals of the static version of the baseline model. There are several residual based panel data cointegration tests available in the literature. Levin and Lin (1993) suggest a superconsistent unit root test with limiting normal distribution. Im et al. (1996) propose a more general test, allowing parameter heterogeneity in the testing regressions but implicitly requiring a balanced panel for the test to be valid. Given the unbalanced nature of our data, we use the test suggested by Maddala and Wu (1996) using previous findings by

\footnotetext{
${ }^{28} \mathrm{~A}$ further possible simplification is the restriction of a common autoregressive parameter across countries that reduces the number of parameters of $\hat{\Omega}$ to $N$. Imposing this restriction to our model does not alter the estimation results in any systematic way.

${ }^{29}$ See Dickey and Fuller (1979). The number of lags used to calculate the Newey-West estimate of variance is int $\left[4(N / 100)^{\frac{2}{9}}\right]$, where $N$ is the number of observations in the series.
} 


\begin{tabular}{cccccccccccccc}
\hline \hline country & UR & EP & BRR & BD & UD & $\Delta$ UD & CO & TW & D2TFP & D2MS & RIRL & TTSFC \\
\hline \hline Australia & 1 & 1 & 1 & 1 & 1 & 1 & 1 & 1 & 0 & 0 & 1 & 0 \\
Austria & 1 & 1 & 1 & 1 & 1 & 0 & 1 & 1 & 1 & 0 & 1 & 0 \\
Belgium & 1 & 1 & 1 & 1 & 1 & 1 & 1 & 1 & 0 & 0 & 1 & 1 \\
Canada & 1 & 1 & 1 & 1 & 1 & 0 & 1 & 1 & 1 & 0 & 1 & 0 \\
Denmark & 1 & 1 & 1 & 1 & 1 & 0 & 1 & 1 & 0 & 0 & 1 & 0 \\
Finland & 1 & 1 & 1 & 1 & 1 & 0 & 1 & 1 & 1 & 0 & 1 & 0 \\
France & 1 & 1 & 1 & 1 & 1 & 0 & 1 & 1 & 1 & 0 & 1 & 0 \\
Germany & 1 & 1 & 1 & 1 & 1 & 1 & 1 & 1 & 1 & 0 & 0 & 0 \\
Ireland & 1 & 1 & 1 & 1 & 1 & 0 & 1 & 1 & 1 & 0 & 0 & 0 \\
Italy & 1 & 1 & 1 & 1 & 1 & 0 & 1 & 1 & 1 & 0 & 1 & 0 \\
Japan & 1 & 1 & 1 & 1 & 1 & 0 & 1 & 1 & 1 & 0 & 1 & 0 \\
Netherlands & 1 & 1 & 1 & 1 & 1 & 0 & 1 & 1 & 0 & 0 & 1 & 0 \\
Norway & 1 & 1 & 1 & 1 & 1 & 0 & 1 & 1 & 1 & 0 & 1 & 0 \\
New Zealand & 1 & 1 & 1 & 1 & 1 & 1 & 1 & 0 & 1 & 0 & 0 & 0 \\
Portugal & 1 & 1 & 1 & 1 & 1 & 1 & 1 & 1 & 1 & 0 & 1 & 0 \\
Spain & 1 & 1 & 1 & 1 & 1 & 1 & 1 & 1 & 0 & 0 & 1 & 0 \\
Sweden & 1 & 1 & 1 & 1 & 1 & 0 & 1 & 1 & 1 & 0 & 1 & 0 \\
Switzerland & 1 & 1 & 1 & 1 & 1 & 0 & 1 & 1 & 1 & 0 & 0 & 0 \\
UK & 1 & 1 & 1 & 1 & 1 & 0 & 1 & 1 & 1 & 0 & 1 & 0 \\
US & 1 & 1 & 1 & 0 & 1 & 0 & 1 & 1 & 1 & 0 & 1 & 0 \\
\hline \hline
\end{tabular}

Table 5: Unit roots in country time series

Fisher (1932). This test combines the results of $N$ by country unit roots tests of any kind, each with $\mathrm{P}$-value $P_{i}$, in the statistic $-2 \sum \log P_{i}$, shown to be $\chi^{2}$ distributed with $2 N$ degrees of freedom. It relies on the assumption of no cross country correlation and whenever this assumption is not met Maddala and Wu suggest bootstrapping to define the critical values. In our model we control for cross country correlation by means of time dummies, and therefore we assume to be free to use the exact distribution of the test for inference.

Table 6 shows two versions of the cointegration test, using respectively Dickey Fuller with trend and Phillips Perron ${ }^{30}$ as by country tests. The P-values are MacKinnon approximations. The null hypothesis of no cointegration is rejected in both cases.

\subsection{Endogeneity Tests}

The labour cost equation could be affected by the potential endogeneity of labour market institutions and unemployment. As regards the unemployment rate, we expect the endogeneity bias, if present, to be of a conservative kind, as the causal directions from unemployment to wages and vice versa are in opposite direction. For what concerns institutions, we test the endogeneity hypothesis by means of the Durbin-Wu-Hausman test (DWH). This augmented regression test examines whether the endogeneity of some of

\footnotetext{
${ }^{30}$ See Dickey and Fuller (1979) and Phillips and Perron (1988).
} 


\begin{tabular}{lc}
\hline \hline & Baseline model \\
\hline \hline Fisher panel statistic of & $\chi_{(40)}^{2}=96.31$ \\
Dickey Fuller test (w.t.) & P-value $\simeq 0.000$ \\
Fisher panel statistic of & $\chi_{(40)}^{2}=99.75$ \\
Phillips Perron test & P-value $\simeq 0.000$ \\
\hline \hline
\end{tabular}

Table 6: Tests for cointegration in panel regression

the regressors causes the OLS estimator to be inconsistent, suggesting the adoption of instrumental variables ${ }^{31}$

There are various ways of calculating the DWH test, the simplest being the estimation of a set of artificial regressions in which each candidate endogenous variable is regressed upon the vector of all instruments and exogenous variables. As a second stage the residuals of each artificial regression are included in the original model and their joint significance tested. The intuition behind this methodology is that if the original specification is correct, then the additional regressors are redundant. The tests are performed using a set of political variables provided by the Comparative Welfare State Dataset ${ }^{32}$ as instruments for institutions. These are: the percentage of total votes for left, center and right parties in each country; the percentage of left, center and right seats in parliament; the left, center and right seats as a percentage of seats held by all government parties; the cumulative score of left, center and right parties from 1946 to the year of the observation. Table 7 presents the results for the DWH tests using the percentage of left and right seats in parliament as instruments. Each column reports the tests for each single variable. In all cases the null hypothesis of independence between institutions and the stochastic error is not rejected. The same DWH tests were carried on using other combination of political variables as instruments with similar results.

Although these results give us some confidence in the interpretation of our empirical model, the question of the endogeneity of labour market institutions is still open and will need further investigation in the future. It is reasonable to assume that the evolution of labour market institutions in OECD countries has been influenced by the status of the labour market in each country. However, the identification of the way institutional change has been shaped is not obvious. The characteristics of the political deliberation process in each country seem to suggest that the causal nexus is profoundly shaped by other factors such as the voters' preference structure, the policy makers' agenda, the existence of stable political equilibria and the timing of elections, among the others.

\footnotetext{
${ }^{31}$ See Hausman (1978) and the discussion in MacKinnon (1992). Note that the object of the test is not the endogeneity of some regressors but the effect of endogeneity, if present, on the estimates of the parameters of interest.

${ }^{32}$ The Comparative Welfare State Dataset is assembled by Huber E., Ragin C., Stephens J. at University of North Carolina and Northwestern University. The dataset contains data on socio political variables collected for all countries in the sample, except Portugal and Spain, from 1960 to 1994. The results about each country elections votes are classified according to the political inspiration of each party involved. The parties are divided into three main groups: left, center and right parties.
} 


\begin{tabular}{cccccc}
\hline \hline & BR & EP & $\Delta$ UD & CO & TW \\
\hline \hline DWH test & $F_{(1,443)}=.09$ & $F_{(1,443)}=0.19$ & $F_{(1,443)}=0.07$ & $F_{(1,443)}=0.22$ & $F_{(1,443)}=0.18$ \\
& P-value $\simeq 0.76$ & P-value $\simeq 0.76$ & P-value 0.79 & P-value $\simeq 0.64$ & P-value $\simeq 0.67$ \\
\hline \hline
\end{tabular}

Table 7: Durbin - Wu - Hausman tests

\section{Estimation Results}

We present a set of alternative specifications of the labour cost model. These are:

1. the baseline model;

2. including $\Delta T W$;

3. including $T W_{t-1}$ and $\Delta T W_{t-1}$, to check for a lagged effect of the tax wedge;

4. including Union Density, also interacted with unemployment rate and productivity;

5. including Oswald's Home Ownership variable (Portugal excluded) which represents the proportion of owner occupier households and is a proxy for labour mobility;

6. excluding Portugal for comparison with the previous model;

7. wage equation (i.e. replacing unemployment with its log in the level, delta and interactions effects);

8. including a structural break in the productivity trend;

9. including further shocks;

10. using an alternative measure of bargaining coordination;

11. including coordination types dummies;

12. check 1 of Daveri and Tabellini result, dividing the countries into three groups according to their degree of bargaining coordination;

13. check 2 of Daveri and Tabellini result, dividing the countries into three groups according to their degree of bargaining centralization;

14. estimation on a subsample from 1970;

15. with log unemployment and unemployment growth rate;

16. with $\log$ unemployment and unemployment growth rate also interacted with coordination;

17. the static model;

18. the baseline model estimated by OLS. 


\begin{tabular}{|c|c|c|c|c|c|c|c|c|c|}
\hline & LÅ & LÅ & LÅ & LÅ & LABC & $\begin{array}{c}(6) \\
\text { LABC }\end{array}$ & $\begin{array}{c}(7) \\
\text { LÅBC }\end{array}$ & LÅBC & LÅ) \\
\hline$\overline{\mathrm{LABC}(-1)}$ & 0.697 & $\overline{0.696}$ & $\overline{0.711}$ & $\overline{0.707}$ & $\overline{0.687}$ & $\overline{0.696}$ & $\overline{0.708}$ & $\overline{0.694}$ & $\overline{0.688}$ \\
\hline & [30.29] & [29.98] & [29.87] & [31.71] & [29.12] & [30.10] & [29.65] & [29.76] & [29.29] \\
\hline $\mathrm{U}$ & -0.499 & $-\mathbf{0 . 4 7 6}$ & -0.430 & -0.505 & $-\mathbf{0 . 4 7 4}$ & $-\mathbf{0 . 4 9 5}$ & $-\mathbf{0 . 0 1 5}$ & -0.488 & $-\mathbf{0 . 5 2 7}$ \\
\hline $\mathrm{EP}$ & $\begin{array}{l}\mathbf{0 . 0 2 3} \\
4.77]\end{array}$ & $\begin{array}{l}\mathbf{0 . 0 2 4} \\
{[5.02]}\end{array}$ & 0.023 & $\begin{array}{l}\mathbf{0 . 0 2 0} \\
{[3.89]}\end{array}$ & $\begin{array}{l}\mathbf{0 . 0 1 8} \\
{[3.40]}\end{array}$ & $\begin{array}{l}\mathbf{0 . 0 2 4} \\
{[4.87]}\end{array}$ & $\begin{array}{l}\mathbf{0 . 0 2 6} \\
{[5.10]}\end{array}$ & $\begin{array}{l}\mathbf{0} .024 \\
{[4.85]}\end{array}$ & $\begin{array}{c}\mathbf{0 . 0 2 0} \\
{[3.79]}\end{array}$ \\
\hline BRR & $\begin{array}{l}\mathbf{0 . 0 3 7} \\
{[3.07]}\end{array}$ & $\begin{array}{l}\mathbf{0 . 0 4 1} \\
{[3.40]}\end{array}$ & $\begin{array}{l}\mathbf{0 . 0 3 9} \\
{[3.05]}\end{array}$ & $\begin{array}{l}\mathbf{0 . 0 2 8} \\
{[2.26]}\end{array}$ & $\begin{array}{r}\mathbf{0 . 0 3 7} \\
{[2.98]}\end{array}$ & $\begin{array}{l}\mathbf{0 . 0 3 5} \\
{[2.84]}\end{array}$ & $\begin{array}{l}\mathbf{0 . 0 3 8} \\
{[2.90]}\end{array}$ & $\begin{array}{l}\mathbf{0 . 0 3 5} \\
{[2.90]}\end{array}$ & $\begin{array}{c}\mathbf{0 . 0 4 4} \\
{[3.55]}\end{array}$ \\
\hline TW & $\begin{array}{l}\mathbf{0 . 1 1 6} \\
{[3.90]}\end{array}$ & $\begin{array}{l}\mathbf{0 . 0 9 0} \\
{[2.71]}\end{array}$ & $\begin{array}{l}\mathbf{0 . 0 7 1} \\
{[1.90]}\end{array}$ & $\begin{array}{l}\mathbf{0 . 1 0 7} \\
{[3.63]}\end{array}$ & $\begin{array}{l}\mathbf{0 . 1 0 7} \\
{[3.61]}\end{array}$ & $\begin{array}{l}\mathbf{0 . 1 0 8} \\
{[3.59]}\end{array}$ & $\mathbf{0 . 0 8 7}$ & $\mathbf{0 . 1 1 5}$ & $\mathbf{0 . 1 0 1}$ \\
\hline $\mathrm{CO}$ & $\begin{array}{c}-\mathbf{0 . 0 2 6} \\
{[2.57]}\end{array}$ & $\begin{array}{c}-\mathbf{0 . 0 2 5} \\
{[2.45]}\end{array}$ & $\begin{array}{c}-\mathbf{0 . 0 2 6} 6 \\
{[2.47]}\end{array}$ & $\begin{array}{c}-\mathbf{0 . 0 2 3} \\
{[2.17]}\end{array}$ & $\begin{array}{c}-\mathbf{0 . 0 2 4} \\
{[2.32]}\end{array}$ & $\begin{array}{c}-\mathbf{0 . 0 2 6} \\
{[2.54]}\end{array}$ & $\begin{array}{c}-\mathbf{0 . 0 4 5} \\
{[4.51]}\end{array}$ & $\begin{array}{c}-\mathbf{0 . 0 2 7} \\
{[2.63]}\end{array}$ & $\begin{array}{c}-\mathbf{0 . 0 2 9} \\
{[2.75]}\end{array}$ \\
\hline$\Delta \mathrm{UD}$ & $\begin{array}{l}\mathbf{0 . 2 0 2} \\
{[2.73]}\end{array}$ & $\begin{array}{l}\mathbf{0 . 2 2 2} \\
{[2.97]}\end{array}$ & $\begin{array}{l}\mathbf{0 . 1 5 8} \\
{[2.11]}\end{array}$ & $\begin{array}{l}\mathbf{0 . 2 2 5} \\
{[3.03]}\end{array}$ & $\begin{array}{l}\mathbf{0 . 1 7 6} \\
{[2.33]}\end{array}$ & $\begin{array}{l}\mathbf{0 . 1 8 5} \\
{[2.46]}\end{array}$ & $\begin{array}{l}\mathbf{0 . 1 8 2} \\
{[2.36]}\end{array}$ & $\begin{array}{l}\mathbf{0 . 2 0 2} \\
{[2.72]}\end{array}$ & $\begin{array}{l}\mathbf{0 . 1 4 2} \\
{[1.92]}\end{array}$ \\
\hline URCO & -0.193 & $-\mathbf{0 . 1 9 9}$ & -0.157 & -0.241 & -0.197 & -0.195 & $\mathbf{0 . 0 0 4}$ & -0.186 & -0.174 \\
\hline URBRR & $\begin{array}{l}\mathbf{0 . 4 4 1} \\
{[2.08]}\end{array}$ & $\begin{array}{l}\mathbf{0 . 3 9 2} \\
{[1.81]}\end{array}$ & $\begin{array}{l}\mathbf{0 . 2 7 1} \\
{[1.25]}\end{array}$ & $\begin{array}{c}\mathbf{0 . 4 8 2} \\
{[2.22]}\end{array}$ & $\begin{array}{l}\mathbf{0 . 3 4 6} \\
{[1.67]}\end{array}$ & $\begin{array}{l}\mathbf{0 . 4 1 4} \\
{[1.96]}\end{array}$ & $\begin{array}{l}\mathbf{0 . 0 1 0} \\
{[1.01]}\end{array}$ & $\begin{array}{l}\mathbf{0 . 4 1 1} \\
{[1.93]}\end{array}$ & $\begin{array}{l}\mathbf{0 . 3 3 7} \\
{[1.61]}\end{array}$ \\
\hline URUD & $\begin{array}{l}\mathbf{0 . 4 0 5} \\
{[2.08]}\end{array}$ & $\begin{array}{l}\mathbf{0 . 3 7 4} \\
{[1.88]}\end{array}$ & $\begin{array}{l}\mathbf{0 . 3 2 7} \\
{[1.67]}\end{array}$ & $\begin{array}{l}\mathbf{0 . 4 1 0} \\
{[2.02]}\end{array}$ & $\begin{array}{l}\mathbf{0 . 4 6 6} \\
{[2.50]}\end{array}$ & $\begin{array}{l}\mathbf{0 . 4 2 8} \\
{[2.28]}\end{array}$ & $\begin{array}{l}\mathbf{0 . 0 0 1} \\
{[0.05]}\end{array}$ & $\begin{array}{l}\mathbf{0 . 3 9 0} \\
{[2.01]}\end{array}$ & $\begin{array}{l}\mathbf{0 . 3 9 1} \\
{[2.09]}\end{array}$ \\
\hline TWCO & $\begin{array}{r}-\mathbf{0 . 1 4 1} \\
{[4.32]}\end{array}$ & $\begin{array}{r}-\mathbf{0 . 1 4 8} \\
{[4.60]}\end{array}$ & $\begin{array}{r}-\mathbf{0 . 0 9 4} \\
{[2.57]}\end{array}$ & $\begin{array}{r}-\mathbf{0 . 1 4 1} \\
{[4.41]}\end{array}$ & $\begin{array}{r}-0.127 \\
{[3.91]}\end{array}$ & $\begin{array}{r}-\mathbf{0 . 1 4 1} \\
{[4.31]}\end{array}$ & $\begin{array}{r}-0.103 \\
{[3.11]}\end{array}$ & $\begin{array}{r}-\mathbf{0 . 1 3 3} \\
{[4.10]}\end{array}$ & $\begin{array}{r}-\mathbf{0 . 1 4 7} \\
{[4.54]}\end{array}$ \\
\hline$\pi$ & $\begin{array}{l}\mathbf{0 . 4 7 1} \\
{[12.64]}\end{array}$ & $\begin{array}{l}\mathbf{0 . 4 6 9} \\
{[12.28]}\end{array}$ & $\begin{array}{l}\mathbf{0 . 4 4 4} \\
{[11.57]}\end{array}$ & $\begin{array}{l}\mathbf{0 . 4 4 5} \\
{[12.41]}\end{array}$ & $\begin{array}{l}\mathbf{0 . 5 0 3} \\
{[12.06]}\end{array}$ & $\begin{array}{l}\mathbf{0 . 4 6 7} \\
{[12.53]}\end{array}$ & $\begin{array}{l}0.441 \\
{[11.63]}\end{array}$ & $\begin{array}{l}\mathbf{0 . 4 6 8} \\
{[12.60]}\end{array}$ & $\begin{array}{l}\mathbf{0 . 5 0 5} \\
{[11.62]}\end{array}$ \\
\hline D2TFP & $\begin{array}{c}-\mathbf{0 . 3 8 1} \\
{[3.95]}\end{array}$ & $\begin{array}{r}-0.401 \\
{[4.17]}\end{array}$ & $\begin{array}{r}-\mathbf{0 . 4 2 9} \\
{[4.41]}\end{array}$ & $\begin{array}{c}-\mathbf{0 . 3 5 9} \\
{[3.74]}\end{array}$ & $\begin{array}{c}-\mathbf{0 . 4 3 4} \\
{[4.47]}\end{array}$ & $\begin{array}{r}-0.401 \\
{[4.10]}\end{array}$ & $\begin{array}{l}-0.442 \\
{[4.38]}\end{array}$ & $\begin{array}{r}-\mathbf{0 . 3 9 9} \\
{[4.14]}\end{array}$ & $\begin{array}{c}-\mathbf{0 . 4 1 4} \\
{[4.25]}\end{array}$ \\
\hline TTS & $\mathbf{0 . 3 6 4}$ & $\mathbf{0 . 3 8 1}$ & $\mathbf{0 . 3 1 1}$ & $\mathbf{0 . 2 8 7}$ & $\begin{array}{l}\mathbf{0 . 3 7 2} \\
{[7,09]}\end{array}$ & $\mathbf{0 . 3 6 8}$ & $\begin{array}{l}\mathbf{0 . 3 3 0} \\
5587]\end{array}$ & $\mathbf{0 . 3 6 5}$ & $\begin{array}{l}\mathbf{0 . 3 0 7} \\
55,69]\end{array}$ \\
\hline $\begin{array}{l}\Delta \mathrm{TW} \\
\pi \cdot \mathrm{UD}\end{array}$ & & $\begin{array}{l}\mathbf{0 . 0 9 3} \\
{[1.72]}\end{array}$ & $\begin{array}{c}-\mathbf{0 . 0 6 7} \\
{[1.25]}\end{array}$ & $\begin{array}{l}\mathbf{0 . 0 7 6} \\
{[4.64]}\end{array}$ & & & & & \\
\hline Constant & $\begin{array}{l}\mathbf{2 . 7 1 8} \\
{[0.44]}\end{array}$ & $\begin{array}{l}\mathbf{0 . 9 4 8} \\
{[0.15]}\end{array}$ & $\begin{array}{l}\mathbf{1 . 0 2 6} \\
{[0.61]}\end{array}$ & $\begin{array}{c}-\mathbf{0 . 6 0 8} \\
{[0.37]}\end{array}$ & $\begin{array}{l}\mathbf{1 . 2 4 7} \\
{[0.69]}\end{array}$ & $\begin{array}{c}-\mathbf{0 . 1 0 5} \\
{[0.06]}\end{array}$ & $\begin{array}{l}\mathbf{0 . 7 1 7} \\
{[0.41]}\end{array}$ & $\begin{array}{c}\mathbf{- 0 . 4 3 8} \\
{[0.25]}\end{array}$ & $\begin{array}{r}4.565 \\
{[1.64]} \\
-0.006\end{array}$ \\
\hline RIRL & & & & & & & & & $\begin{array}{l}0.130 \\
{[3.72]}\end{array}$ \\
\hline$\pi \cdot \mathrm{d} 70$ & & & & & & & & $\begin{array}{c}-\mathbf{0 . 0 0 2} \\
{[1.01]}\end{array}$ & \\
\hline HOUSE & & & & & $\begin{array}{c}\mathbf{0 . 1 4 0} \\
{[1.80]}\end{array}$ & & & & \\
\hline UD & & & & $\begin{array}{c}\mathbf{0 . 0 0 3} \\
{[0.11]}\end{array}$ & & & & & \\
\hline $\begin{array}{c}\text { Obs } \\
\text { Countries }\end{array}$ & $\begin{array}{l}572 \\
20\end{array}$ & $\begin{array}{c}570 \\
20\end{array}$ & $\begin{array}{c}569 \\
20\end{array}$ & $\begin{array}{c}572 \\
20\end{array}$ & $\begin{array}{c}553 \\
19\end{array}$ & $\begin{array}{c}553 \\
19\end{array}$ & $\begin{array}{c}561 \\
20\end{array}$ & $\begin{array}{c}572 \\
20\end{array}$ & $\begin{array}{c}559 \\
20\end{array}$ \\
\hline av. T & 29.58 & 29.55 & 29.48 & 29.58 & 29.95 & 29.95 & 29.12 & 29.58 & 29.09 \\
\hline Pval $\mathrm{Cf}=0$ & 0.00 & 0.00 & 0.00 & 0.00 & 0.00 & 0.00 & 0.00 & 0.00 & 0.00 \\
\hline Pval f.e. $=0$ & 0.00 & 0.00 & 0.00 & 0.00 & 0.00 & 0.00 & 0.00 & 0.00 & 0.00 \\
\hline $\begin{array}{l}\text { LABC is log re } \\
\text { NOTES: Gene } \\
\text { contains count } \\
\text { deviations fron } \\
\text { density (UD), } \\
\text { Employment } \\
\text { D2TFP is the } \\
\text { z statistics in }\end{array}$ & $\begin{array}{l}n(E P) \\
\text { tion in }\end{array}$ & co-ordin & (CO) ar & ces ( $\mathrm{rar}$ & $-1.1,0-2$ & respecti & (iii) $\pi$ & produc & $\begin{array}{l}\text { cers. } \\
\text { uation } \\
\text { as } \\
\text { on } \\
0-1) \text {. } \\
\text { trend, } \\
\text { est rate. }\end{array}$ \\
\hline
\end{tabular}

Table 8: OECD Labour Cost Models: 1960-1994 


\begin{tabular}{|c|c|c|c|c|c|c|c|c|c|}
\hline & $\begin{array}{c}(10) \\
\text { LABC }\end{array}$ & $\begin{array}{c}(11) \\
\text { LABC }\end{array}$ & $\begin{array}{l}(12) \\
\text { LABC }\end{array}$ & $\begin{array}{l}(13) \\
\text { LABC }\end{array}$ & $\begin{array}{l}(14) \\
\text { LABC }\end{array}$ & $\begin{array}{l}(15) \\
\text { LABC }\end{array}$ & $\begin{array}{l}(16) \\
\text { LABC }\end{array}$ & $\begin{array}{c}(17) \\
\text { LABC }\end{array}$ & $\begin{array}{c}(18) \\
\text { LABC }\end{array}$ \\
\hline$\overline{\mathrm{LABC}(-1)}$ & 0.726 & 0.682 & 0.691 & 0.700 & 0.688 & 0.705 & 0.700 & & 0.659 \\
\hline IU & {$[32.79]$} & {$[29.37]$} & {$[28.67]$} & {$[29.64]$} & [23.53] & {$[29.88]$} & {$[29.16]$} & 0772 & {$[19.94]$} \\
\hline U & $\begin{array}{c}-0.519 \\
{[7.17]}\end{array}$ & $\begin{array}{c}-0.536 \\
{[7.50]}\end{array}$ & $\begin{array}{c}-0.352 \\
{[5.09]}\end{array}$ & $\begin{array}{c}-0.414 \\
{[5.96]}\end{array}$ & $\begin{array}{c}-\mathbf{0 . 2 2 0} \\
{[2.87]}\end{array}$ & $\begin{array}{c}-0.455 \\
{[6.59]}\end{array}$ & $\begin{array}{c}-0.439 \\
{[6.32]}\end{array}$ & $\begin{array}{c}-0.762 \\
6.70]\end{array}$ & $\begin{array}{c}-0.534 \\
{[5.00]}\end{array}$ \\
\hline $\mathrm{EP}$ & $\begin{array}{l}\mathbf{0 . 0 2 4} \\
{[4.80]}\end{array}$ & $\begin{array}{l}\mathbf{0 . 0 2 2} \\
{[4.53]}\end{array}$ & 0.018 & $\begin{array}{l}\mathbf{0 . 0 1 8} \\
{[3.74]}\end{array}$ & $\begin{array}{c}-\mathbf{0 . 0 0 4} \\
{[0.45]}\end{array}$ & $\begin{array}{l}\mathbf{0 . 0 2 5} \\
{[5.56]}\end{array}$ & $\begin{array}{l}\mathbf{0} \\
{[6.57]}\end{array}$ & $\begin{array}{l}\mathbf{0 . 0 3 7} \\
{[4.36]}\end{array}$ & $\begin{array}{l}\mathbf{0 . 0 0 3} \\
{[0.29]}\end{array}$ \\
\hline BRR & 0.040 & 0.042 & 0.029 & $\mathbf{0 . 0 3 6}$ & 0.058 & 0.033 & 0.034 & 0.084 & 0.010 \\
\hline TW & $\begin{array}{l}{[3.27]} \\
\mathbf{0 . 0 5 9} \\
{[2.07]}\end{array}$ & $\begin{array}{l}{[3.43]} \\
\mathbf{0 . 1 1 9} \\
{[3.92]}\end{array}$ & & & $\begin{array}{l}{[4.04]} \\
\mathbf{0 . 0 9 5} \\
{[2.98]}\end{array}$ & $\begin{array}{l}{[2.71]} \\
\mathbf{0 . 1 0 3} \\
{[3.40]}\end{array}$ & $\begin{array}{l}{[2.80]} \\
\mathbf{0 . 1 0 5} \\
{[3.46]}\end{array}$ & $\begin{array}{l}{[4.57]} \\
\mathbf{0 . 3 2 2} \\
{[6.78]}\end{array}$ & $\begin{array}{l}{[0.55]} \\
\mathbf{0 . 0 6 5} \\
{[1.46]}\end{array}$ \\
\hline $\mathrm{CO}$ & $\begin{array}{l}-0.004 \\
{[1.01]}\end{array}$ & $-\mathbf{0 . 0 2 7}$ & $\begin{array}{r}-\mathbf{0 . 0 3 2} \\
{[2.79]}\end{array}$ & $\begin{array}{c}-\mathbf{0 . 0 2 6} \\
{[2.42]}\end{array}$ & $\begin{array}{r}-0.025 \\
{[2.35]}\end{array}$ & $\begin{array}{r}-\mathbf{0 . 0 2 8} \\
{[281]}\end{array}$ & $\begin{array}{c}-0.034 \\
{[3.38]}\end{array}$ & $\begin{array}{r}-\mathbf{0 . 1 4 1} \\
{[8.70]}\end{array}$ & $\begin{array}{r}-\mathbf{0 . 0 0 7} \\
{[0.43]}\end{array}$ \\
\hline$\Delta \mathrm{UD}$ & $\begin{array}{l}\mathbf{0 . 1 3 2} \\
{[1.80]}\end{array}$ & $\begin{array}{l}\mathbf{0 . 2 4 3} \\
{[3.30]}\end{array}$ & $\begin{array}{l}0.218 \\
{[2.90]}\end{array}$ & $\begin{array}{l}\mathbf{0 . 2 0 5} \\
{[2.73]}\end{array}$ & $\begin{array}{l}0.271 \\
{[3.13]}\end{array}$ & $\begin{array}{c}\mathbf{0 . 2 3 6} \\
{[3.14]}\end{array}$ & 0.242 & $\begin{array}{r}\mathbf{0 . 3 4 1} \\
{[2.68]}\end{array}$ & $\begin{array}{r}\mathbf{0 . 2 7 2} \\
{[2.97]}\end{array}$ \\
\hline URCO & $\begin{array}{l}-0.207 \\
{[3.34]}\end{array}$ & $\begin{array}{c}-\mathbf{0 . 1 9 3} \\
{[2.61]}\end{array}$ & $\begin{array}{r}-0.139 \\
{[1.89]}\end{array}$ & $\begin{array}{r}-0.132 \\
{[1.79]}\end{array}$ & $\begin{array}{r}-0.099 \\
{[1.44]}\end{array}$ & $\begin{array}{r}-0.157 \\
{[2.39]}\end{array}$ & $\begin{array}{l}-0.105 \\
{[1.71]}\end{array}$ & $\begin{array}{r}-\mathbf{0 . 1 1 0} \\
{[0.86]}\end{array}$ & $\begin{array}{c}-\mathbf{0 . 3 9 3} \\
{[2.75]}\end{array}$ \\
\hline URBRR & $\mathbf{0 . 6 0 1}$ & $\begin{array}{r}\mathbf{0 . 4 2 1} \\
{[1.98]}\end{array}$ & $\begin{array}{l}\mathbf{0 . 0 8 7} \\
{[0.39]}\end{array}$ & $\begin{array}{l}\mathbf{0 . 3 0 4} \\
{[1.39]}\end{array}$ & $\begin{array}{l}-0.337 \\
{[1.44]}\end{array}$ & $\begin{array}{l}\mathbf{0 . 3 3 9} \\
{[1.61]}\end{array}$ & $\begin{array}{l}\mathbf{0 . 3 4 7} \\
{[1.62]}\end{array}$ & $\begin{array}{l}\mathbf{0 . 7 5 0} \\
{[2.40]}\end{array}$ & $\begin{array}{l}\mathbf{0 . 2 6 1} \\
{[0.88]}\end{array}$ \\
\hline URUD & $\mathbf{0 . 4 0 0}$ & $\begin{array}{l}\mathbf{0 . 3 4 9} \\
{[1.82]}\end{array}$ & $\begin{array}{l}\mathbf{0 . 3 4 9} \\
{[1.80]}\end{array}$ & $\begin{array}{l}\mathbf{0 . 2 8 1} \\
{[1.44]}\end{array}$ & $\begin{array}{l}\mathbf{0 . 1 0 3} \\
{[0.48]}\end{array}$ & $\begin{array}{l}\mathbf{0 . 3 5 9} \\
{[1.85]}\end{array}$ & $\begin{array}{l}\mathbf{0 . 3 2 2} \\
{[1.63]}\end{array}$ & $\mathbf{0 . 7 5 1}$ & $\begin{array}{l}\mathbf{0 . 0 5 9} \\
{[0.24]}\end{array}$ \\
\hline TWCO & 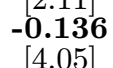 & $\begin{array}{c}{[\mathbf{0 . 1 3 9}} \\
{[4.13]}\end{array}$ & & & $\begin{array}{c}{[0.089} \\
-0.089 \\
{[2.46]}\end{array}$ & $\begin{array}{c}-\mathbf{0 . 1 3 3} \\
{[4.01]}\end{array}$ & $\begin{array}{c}-\mathbf{0 . 1 3 2}] \\
{[3.93]}\end{array}$ & $\begin{array}{r}-0.152 \\
{[2.57]}\end{array}$ & $\begin{array}{c}{[0.24]} \\
-0.071 \\
{[1.28]}\end{array}$ \\
\hline$\pi$ & $\begin{array}{l}\mathbf{0 . 4 2 3} \\
{[11.51]}\end{array}$ & $\begin{array}{l}\mathbf{0 . 4 8 9} \\
{[12.95]}\end{array}$ & $\begin{array}{l}\mathbf{0 . 4 5 4} \\
{[12.17]}\end{array}$ & $\begin{array}{c}\mathbf{0 . 4 3 8} \\
{[11.83]}\end{array}$ & $\begin{array}{l}\mathbf{0 . 4 6 5} \\
{[6.44]}\end{array}$ & $\begin{array}{l}\mathbf{0 . 4 5 7} \\
{[12.02]}\end{array}$ & $\begin{array}{l}\mathbf{0 . 4 6 8} \\
{[11.80]}\end{array}$ & $\begin{array}{l}\mathbf{1 . 3 9 3} \\
{[35.40]}\end{array}$ & $\begin{array}{l}\mathbf{0 . 4 8 9} \\
{[8.52]}\end{array}$ \\
\hline D2TFP & $\begin{array}{c}-0.420 \\
{[4.33]}\end{array}$ & $\begin{array}{c}\mathbf{- 0 . 3 9 2} \\
{[4.08]}\end{array}$ & $\begin{array}{c}-0.439 \\
{[4.55]}\end{array}$ & $\begin{array}{c}-\mathbf{0 . 4 0 4} \\
{[4.22]}\end{array}$ & $\begin{array}{c}-\mathbf{0 . 3 7 9} \\
{[3.58]}\end{array}$ & $\begin{array}{r}-\mathbf{0 . 3 3 7} \\
{[3.49]}\end{array}$ & $\begin{array}{r}-\mathbf{0 . 3 4 5} \\
{[3.57]}\end{array}$ & $\begin{array}{r}-\mathbf{0 . 6 0 8} \\
{[3.75]}\end{array}$ & $\begin{array}{c}-\mathbf{0 . 3 2 8} \\
{[2.90]}\end{array}$ \\
\hline TTS & 0.359 & 0.331 & 0.330 & 0.318 & 0.340 & $\mathbf{0 . 3 3 6}$ & 0.332 & 0.741 & 0.296 \\
\hline$\hat{\gamma}_{U R}$ & {$[6.57]$} & {$[6.22]$} & {$[6.24]$} & {$[6.05]$} & {$[6.17]$} & $\begin{array}{r}{[6.32]} \\
-0.007 \\
{[209]}\end{array}$ & $\begin{array}{r}{[6.24]} \\
-0.000\end{array}$ & {$[7.80]$} & $\begin{array}{l}{[4.39]} \\
\mathbf{0 . 0 0 6}\end{array}$ \\
\hline Constant & -0.934 & -0.335 & 0.492 & -0.503 & 5.529 & 0.277 & 0.439 & -3.329 & -1.893 \\
\hline$\hat{\gamma}_{U R} \cdot \mathrm{CO}$ & {$[0.56]$} & {$[0.20]$} & [0.30] & {$[0.30]$} & {$[1.80]$} & [0.17] & $\begin{array}{r}{[0.27]} \\
-\mathbf{- 0 . 0 1 2} \\
{[2.62]}\end{array}$ & {$[1.10]$} & [0.92] \\
\hline TW.Gunc & & & $\begin{array}{l}\mathbf{0 . 0 7 7} \\
{[2.23]}\end{array}$ & $\begin{array}{l}\mathbf{0 . 0 8 6} \\
{[2.52]}\end{array}$ & & & & & \\
\hline TW.Gint & & & $\begin{array}{l}\mathbf{0 . 1 0 5} \\
3.41]\end{array}$ & $\begin{array}{l}\mathbf{0 . 0 9 4} \\
{[2.91]}\end{array}$ & & & & & \\
\hline TW.Gcoo & & & $\begin{array}{l}\mathbf{0 . 0 7 9} \\
{[2.67]}\end{array}$ & $\begin{array}{l}\mathbf{0 . 0 5 1} \\
{[1.54]}\end{array}$ & & & & & \\
\hline COT1 & & $\mathbf{- 0 . 0 2 2}$ & & & & & & & \\
\hline COT2 & & 0.002 & & & & & & & \\
\hline COT4 & & $\mathbf{0 . 0 0 9}$ & & & & & & & \\
\hline COT5 & & $\mathbf{0 . 0 1 7}$ & & & & & & & \\
\hline COT6 & & $\begin{array}{l}\mathbf{0 . 0 0 2} \\
{[0.42]}\end{array}$ & & & & & & & \\
\hline Obs & 572 & 572 & 572 & 572 & 470 & 572 & 572 & 572 & 572 \\
\hline Countries & 20 & 20 & 20 & 20 & 20 & 20 & 20 & 20 & 20 \\
\hline av. T & 29.58 & 29.58 & 29.58 & 29.58 & 24.02 & 29.58 & 29.58 & 29.58 & 29.58 \\
\hline Pval $\mathrm{Cf}=0$ & 0.00 & 0.00 & 0.00 & 0.00 & 0.00 & 0.00 & 0.00 & 0.00 & 0.00 \\
\hline Pval f.e. $=0$ & 0.00 & 0.00 & 0.00 & 0.00 & 0.00 & 0.00 & 0.00 & 0.00 & 0.00 \\
\hline
\end{tabular}

LABC is log real labour cost per employee, i.e. real unit wages, salaries and social security contributions paid by resident producers.
NOTES: Generalised least squares allowing for heteroskedastic errors and country specific first order serial correlation, OLS in 18 , Each equation contains country dummies, time dummies and country specific trends. (i) When interactions are included, the variables are set as deviations from the mean, so the interactions take the value zero at the sample mean. (ii) The variables unemployment (U), union density (UD), benefit replacement ratio (BRR), employment tax rate (TW) are proportions (range 0-1). Employment protection (EP) and coordination $(\mathrm{CO})$ are indices (ranges $0-1.1,0-2,1-3$ respectively). (iii) $\pi$ is the productivity trend, D2TFP is the acceleration in TFP, TTS is the terms of trade shock, $\hat{\gamma}_{U R}$ is the rate of growth of unemployment, COT1-COT6 are coordination type dummies. TW.Gunc, TW. Gint and TW.Gcoo are interactions between TW and dummies for, respectively, uncoordinated (decentralized), intermediate and coordinated countries in model 12 , decentralized, intermediate and centralized countries in model 13 . z statistics in brackets.

Table 9: OECD Labour Cost Models: 1960-1994 (continued) 
The estimation output is presented in Tables 8 and 9. All models are estimated using a fixed effect GLS estimator, corrected for by country heteroskedasticity and serial correlation, except for Model 18 that is estimated by OLS.

The unemployment coefficient is negative and significant in all specifications. This confirms the theoretical scenario depicted in section 2, showing that the labour market adjustment mechanism is at work. Model 1, our benchmark specification, shows also that the impact of unemployment on wages is shaped by the labour market institutional configuration. The negative wage adjustment triggered by an increase in unemployment is reinforced by higher bargaining coordination, weaker union density and lower unemployment benefits. For what concerns the change in unemployment, we could not find any significance effect.

As regards the level impact of wage pressure institutions, we find a positive significant impact of employment protection, benefit replacement rates, the tax wedge and of an increase in union density. The benefit duration indicator is instead never significant. Coordination has a negative effect on wages, both in level and through the interactions with the tax wedge and unemployment. This result is some way in line with the previous findings of Alesina and Perotti (1997) and Daveri and Tabellini (2000) according to which in presence of high bargaining coordination the impact of the tax variable is reduced. However, this specification does not allow to test for the hump shape hypothesis suggested by these authors. Alternative tests of the complementarity effects between the labour tax rate and coordination are therefore provided by Models 12 and 13. In the former model the countries are divided into three groups according to their degree of bargaining coordination, and the resulting indicator variables are interacted with taxation ${ }^{33}$. Gunc is the dummy for the group of uncoordinated countries, characterized by a coordination level $C O<1.5$. Gint is the indicator for the intermediate countries, with $1.5 \leq C O \leq 2$, and $G c o o$ is the indicator for highly coordinated countries with $C O>2$. Differently from the analysis of the previous papers, here the countries do not belong necessarily to one group for the whole sample period, but they transfer from one group to another according to the institutional changes occurred from the 1960s to the 1990s. The hump shape hypothesis is only partially confirmed by our analysis. In fact, although the coefficient of intermediate countries is the largest, the tax variable has a positive significant impact on all groups of countries and not on the intermediate group only. In addition, although we cannot reject the hypothesis that the three coefficients differ across the three country groups, the long term impact of taxation on labour cost is very similar. For example, a 10 percentage points rise in tax induces a 2.5 percent increase in labour cost in the not coordinated and coordinated countries and a 3.2 percent increase in the intermediate countries.

The test provided by Model 12 is not strictly comparable with the one presented by Alesina and Perotti since they classify the countries according to the degree of centralization in wage bargaining and not of coordination ${ }^{34}$. In order to allow for comparisons Model 13 performs the same test using a time varying centralization indicator for the con-

\footnotetext{
${ }^{33}$ The results below depend only marginally on the definition of coordinated, intermediate and uncoordinated countries, i.e. on the thresholds we use to construct the group dummies. The criteria reported here are the most sensible in order to have enough observations in each group. However, if we adopt alternative reasonable thresholds' values we obtain almost identical coefficients and confidence intervals.

${ }^{34}$ These two variables are positively correlated and have a comparable mean and standard deviation over the sample. Coordination is however more general than centralization, as the latter simply refers to the level at which wages are bargained (plant, firm, industry or economy-wide).
} 
struction of the three dummies. The results are again only moderately in line with the hump shape hypothesis. The impact of the tax variable is not significant in centralized countries only while in decentralized and intermediate countries wages are significantly affected by employment taxation. In this case a 10 percentage points rise in tax induces a 3 percent increase in labour cost in the decentralized and intermediate country groups.

As expected, the productivity trend has a large positive impact on wages. The long run coefficient is greater than one, suggesting that the long run elasticity of substitution between capital and labour is lower than one ${ }^{35}$. The effect is reinforced if unions are stronger, as in Model $4^{36}$.

The TFP and the terms of trade shocks have a significant impact on wages, respectively of negative and positive sign, as expected. This means that labour cost fails to accommodate an acceleration of total factor productivity above the trend while an adverse shock in relative import prices induce workers to maintain their real net incomes, increasing wage pressure. The TFP and the real wage resistance effect are robust to the introduction of another set of shocks, namely the real interest rate and the acceleration in money supply, as in Model 9. The coefficient of the latter variable is not significant, while the interest rate coefficient is significant with positive sign. This finding may be interpreted as a corroboration of the hypothesis suggested above of a positive relation between real interest rate and non human wealth of the unemployed.

In Model 10 we substitute the coordination variable with the measure provided by Nickell et al. (2001) that tries to capture the various detailed nuances of the variations in coordination. In this specification the coordination variable is not significant in level, but still has a significant effect in reinforcing the unemployment wage adjustment mechanism and in reducing the wage pressure impact of the tax variable.

Model 15 includes the unemployment growth rate among the explanatory variables. Its significance with expected sign reinforces the importance of the labour market adjustment mechanism. Moreover, Model 16 shows that the impact of unemployment growth is strengthened when wage bargaining is coordinated, although the change in unemployment becomes insignificant in levels ${ }^{37}$.

Model 11 incorporates a set of dummies that account for changes in types of coordination, based on a taxonomy due to Traxler (1996) and Traxler and Kittel (2000). We include five of the six categorical variables originally set by these authors ${ }^{38}$. These are:

$\mathrm{CO} 1=$ inter associational coordination, i.e. coordination by the major confederations of employers and labour;

\footnotetext{
${ }^{35}$ In analytical terms, we can rewrite a general profit maximizing condition $A F_{1}\left(\frac{A N}{K}, 1\right)=\frac{W}{P \kappa}$ where $N$ is labour, $K$ is capital, $W$ is the labour cost per employee, $P$ is the GDP deflator in aggregate and $\kappa=(1-1 / \eta)$ where $\eta$ is the output demand elasticity. Being $F_{1}$ homogeneous of degree zero in its two arguments, after eliminating $K$ we obtain $N=\frac{Y}{A} h\left(\frac{W}{A P \kappa}\right)$, with $h^{\prime}<0$. Assuming $\kappa$ constant, this can be written in $\log$ linear form as $(w-p)=\alpha_{0}+\frac{1}{\sigma}(y-n)+\frac{\beta_{2}}{\sigma} a$, where $\sigma$ is the long run elasticity of substitution. Our estimates imply that $\sigma<1$. This means that if wages grow faster then productivity, the labour share increases.

${ }^{36}$ This result is in line with previous findings in the literature. For example, Booth et al. (1999) identify a positive impact of unions on wages and productivity through greater gains from training.

${ }^{37}$ We must be however careful in interpreting these results since using unemployment in log form is problematic, as noted at page 4 .

${ }^{38}$ We exclude CO3, pattern setting coordination to avoid multicollinearity.
} 
$\mathrm{CO} 2=$ intra associational coordination, i.e. within the major confederations of employers and labour;

$\mathrm{CO} 4=$ state imposed coordination;

$\mathrm{CO} 5=$ non-coordination;

CO6=state sponsored coordination, i.e. with the state joining the bargaining process as an additional party.

The model confirms again a significant positive impact of an uncoordinated bargaining framework on wages. In addition, the type of coordination that seems to be most relevant in reducing wage pressure is the inter associational ${ }^{39}$.

Model 2 tests for the significance of changes in taxation and Model 3 tests for lagged effects in taxation. In both cases, the variables are insignificant. Model 5 tests for the impact of the home ownership variable, suggested by Oswald as a proxy for labour mobility ${ }^{40}$. The idea here is that if a larger share of households are house owners, then workers will be more reluctant to migrate to different regions in order to find a job. This will reduce the labour market adjustment speed in presence of local adverse shocks, preventing one important allocation mechanism, namely labour mobility, to take place. In our model the home ownership variable has a positive and significant (at the $10 \%$ level) impact on wages, suggesting that lower mobility may also have a wage pressure effect, through the rigid geographical localization of the labour force ${ }^{41}$. In Model 6 we drop the observations from Portugal, in order to make a comparison with Model 5, since no home ownership data is available for that country. As we can see, the model is quite stable after we drop these observations ${ }^{42}$.

In Model 7 we substitute unemployment with its log in order to compare our findings with the wage equation of Blanchflower and Oswald $(1990,1994)$. The long run elasticity of wages with respect to unemployment is 5 percent, i.e. half of the one estimated by Blanchflower and Oswald ${ }^{43}$. This result is not substantially different if we estimate the static version of the model or if we limit our sample to the period 1970-1994.

In Model 8 we test the significance of a split trend in productivity after 1970, interacting $P R O D$ with a dummy equal to 1 for all years after 1970. This is to check if we are able to capture with a split trend in productivity the rapid growth of the share of labour in most countries in the 1960s. The interaction is insignificant, although it is negative as we would expect.

Finally, the labour cost equation is estimated in its static form in Model 17. This is another implicit test of the Pesaran - Smith bias in dynamic heterogeneous panels. The implications of the benchmark model are actually reinforced by the static model.

Overall, the empirical results are robust to different specifications and are coherent with the findings of the unemployment model in the companion paper Nickell et al. The institutions and the unemployment rate have a significant impact on OECD wages, once we control for the productivity trend. The next step is then to establish what proportion

\footnotetext{
${ }^{39}$ The same results are obtained if we drop the coordination variable, $C O$, from the model.

${ }^{40}$ See Oswald (1996).

${ }^{41}$ The real impact of labour mobility may be stronger than the one estimated in Model 5 , as our results may suffer from the high interpolation of the home ownership variable.

${ }^{42}$ This exercize is also useful in order to control for possible "Portugal effects" due to the impact of the Portugal revolution in the 1970s.

${ }^{43}$ This result is however in line with other studies, see for example the analysis of Galiani (1999) for Argentina.
} 
of the wage dynamics from 1960 to 1994 can actually be imputed to changes in institutions and unemployment given productivity. Next section provides some dynamic simulations of the baseline model in order to answer to this question.

\section{Dynamic Simulations}

We present a summary of the results of a set of dynamic simulations performed on the baseline version of the labour cost model. The scope of the dynamic simulations is the measurement of the impact on wages of the evolution of labour market institutions and unemployment from 1960 to 1994 in OECD countries.

The simulations are produced generating a labour cost series for each country through a recursive procedure that substitute the lagged dependent variable with the previous year prediction of the baseline model. The simulated series are then compared with the one obtained using the same method but constraining one or more regressors at their average 1960 s value. In this way we calculate the variation in labour cost that can be imputed to the evolution of the specific regressors over the estimation period.

Obviously, the major part of the rise in wages is due to the productivity trend and relative to this institutions are not important. What is important, however, are the impacts of institutions once we control for productivity.

Figures 1 and 2 show, respectively, the contribution of the changes in institutions and unemployment (from the 1960s average) to the changes in labour costs in the 1980s and in the $1990 \mathrm{~s}^{44}$. From the figures it emerges quite clearly that the role of unemployment is to offset the impact of institutions. In other words, given that wages cannot move too far away from the productivity trend, unemployment has to increase in order to balance the pressure on wages induced by institutions. It follows that the change in unemployment tends to be bigger when the institutional effects are bigger in the opposite direction.

Although the role played by each institution varies across countries and time, we see that, on average, the major labour cost changes are generated by the benefit replacement ratio, taxation and employment protection. Indeed, the simulations display a significant institutional impact in countries that were characterized by a noticeable variation in institutions over the sample period. For example, employment protection regulations do not play any role in countries, such as the non-European and Switzerland, where these regulations did not change substantially from the 1960s. On the other hand, stricter employment protection regulations triggered a wage rise in countries like Portugal, Sweden, Germany and France.

Higher benefit replacement ratios have increased wages in most of the countries in the sample. On the contrary, the fall in the UK ratios had instead a negative impact in that country.

For what concerns coordination, the simulations do not show any effect for the group of countries in which coordination remained stable over the period. However, the increase in coordination in the 1990s was particularly relevant in moderating labour costs in Ireland, France and Italy.

\footnotetext{
${ }^{44}$ Note that, in order to make the simulation figures more informative, they show the predicted percentage change in actual real labour cost, and not in the series in logs.
} 


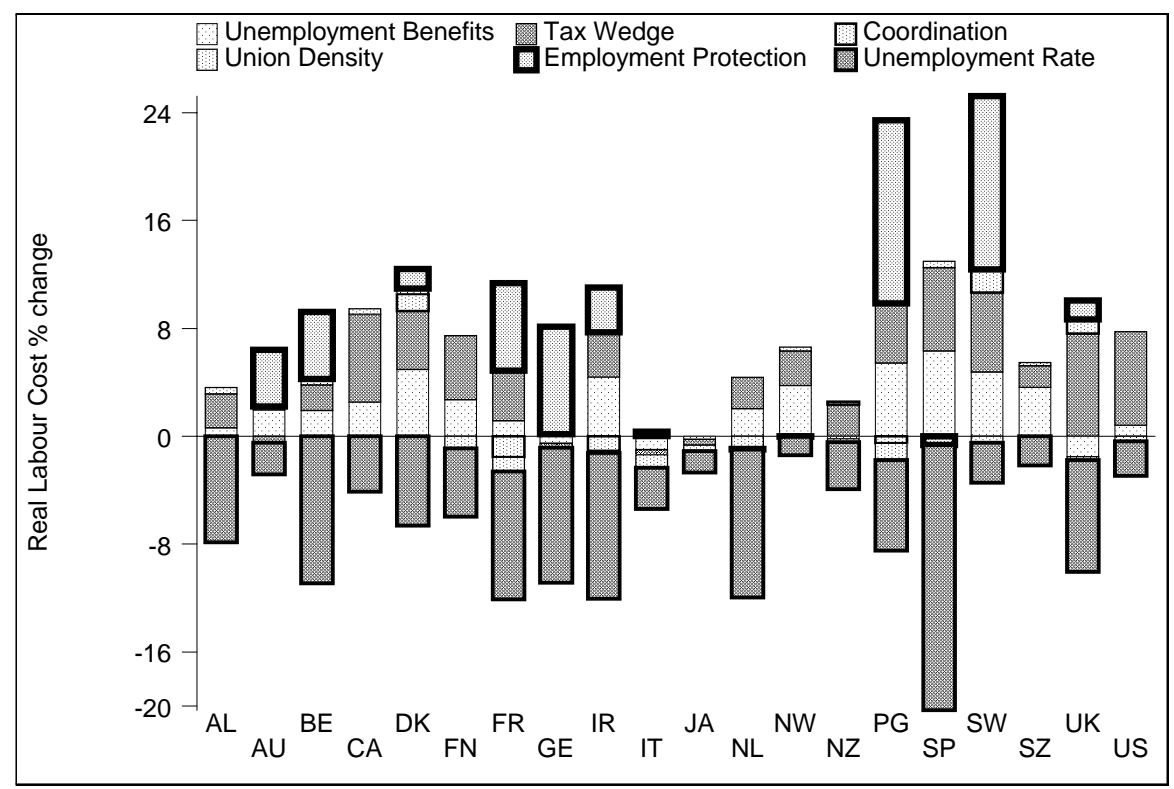

Figure 1: Dynamic simulations with regressors fixed at 1960s average values: percentage changes in labour cost in the 1980s imputed to specific institutional dimensions

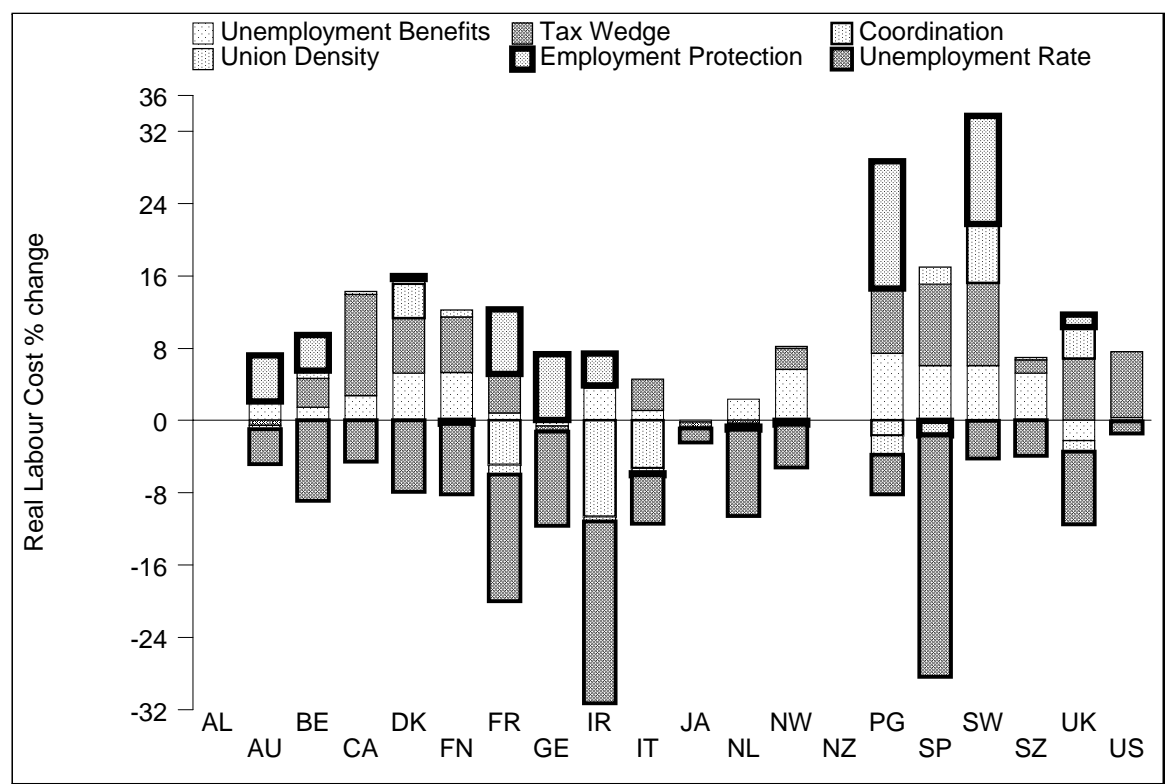

Figure 2: Dynamic simulations with regressors fixed at 1960s average values: percentage changes in labour cost in the 1990s imputed to specific institutional dimensions 


\section{Concluding Remarks}

This paper presents an empirical investigation of the determinants of labour cost in 20 OECD countries observed from 1960 to 1994 . The regressions are estimated using a fixed effects estimator in GLS form, correcting for heteroskedasticity and residual serial correlation. We include year dummies in order to control for contemporaneous correlations and we test for panel cointegration, endogeneity and poolability issues among other things.

The main findings of the paper are the following:

- The unemployment rate has a negative and significant impact on labour cost. Autonomous shocks on unemployment can therefore be offset by labour market forces since higher unemployment triggers a reduction in wages. The estimated long run elasticity of wages with respect to unemployment is 5 percent, i.e. half the one estimated by Blanchflower and Oswald $(1990,1994)$.

- Labour market institutions have a significant impact on wages. The impact can be either direct, inducing wage pressure despite excess supply in the labour market, or indirect, influencing the matching process of unemployed individuals to available job vacancies.

- The effect of institutions is coherent with the results of the unemployment model estimated in the companion paper Nickell et al. (2001). These findings confirm the theoretical scenario depicted in the first part of the paper where equilibrium unemployment is determined by autonomous wage pressure institutions.

- The productivity trend plays a major role in the evolution of wages in OECD countries in the last decades. The employees' productivity gains seem to be higher if unions are stronger. The model does not confirm a structural break in the productivity coefficient after the 1970s.

- Taxation has a positive impact on labour cost. The model confirms therefore the existence of a shift effect from employees to firms, although smaller than the one estimated by previous papers. The tax effect is moderated by high coordination in wage bargaining. The Daveri and Tabellini hypothesis of major impact of the tax wedge in countries with intermediate degree of coordination is only partially confirmed by our analysis. In fact, the tax wedge is significant in uncoordinated, intermediate as well as coordinated countries, and the impact of taxes seems only to be vaguely hump shaped.

- The institutions governing the bargaining process play a major role in shaping wages, both directly as well as through their interaction with unemployment and taxation. Bargaining coordination has a direct negative effect on labour costs, and an indirect effect in reducing the positive impact of taxation and increasing the negative impact of unemployment.

- Stronger unions increase wages, although their adverse effect can be offset by high coordination in wage bargaining. 
- Higher benefit replacement rates have a significant and positive effect on labour cost. They increase workers' utility in case of the unemployment fall back position raising the average reservation wage. In addition, they reduce the effect of labour market adjustment forces induced by higher unemployment.

- The impact of benefit duration is insignificant in all model specifications.

- Employment protection has a positive impact on wages, possibly through the increase in the insiders' rent positions.

- Macroeconomic shocks have a significant effect on wages. In particular, the term of trade shock has a positive effect while the acceleration in TFP growth has a negative impact, showing a certain degree of real wage resistance in OECD economies.

- The home ownership variable, proposed by Oswald as a proxy for low labour mobility has a positive impact on wages. This suggests that if mobility rates are reduced, wages are likely to rise in order to accommodate local labour demand pressure. 


\section{References}

[1] A. Alesina and R. Perotti. The welfare state and competitiveness. American Economic Review, December 1997.

[2] G. Alogoskoufis and Alan Manning. Wage Setting and Unemployment Persistence in Europe, Japan and the USA. European Economic Review, 32:689-706, 1988.

[3] G. S. Bain and R. Price. Profiles of Union Growth : a comparative statistical portrait of eight countries. Basil Blackwell, 1980.

[4] B. Baltagi. Econometric Analysis of Panel Data. Wiley, 1995.

[5] B. Baltagi and Q. Li. Testing AR(1) against MA(1) disturbances in an error component model. Journal of Econometrics, 68, 1995.

[6] G.J. Bamber and R.D. Lansbury (eds). International and Comparative Employment Relations : A Study of Industrialised Market Economies. St. Leonards, 1998.

[7] C. Bean, R. Layard, and S. Nickell. The rise in unemployment: A multi-country study. Economica, 53:S1-S22, 1986.

[8] C.R. Bean. European Unemployment: A Survey. Journal of Economic Literature, 32(2):573-61, June 1994.

[9] N. Beck and J. Katz. What to do (and not to do) with time-series cross-section data. American Political Science Review, 89(3):634-647, September 1995.

[10] M. Belot and J. Van Ours. Does the Recent Success of Some OECD Countries in Lowering their Unemployment Rates Lie in the Clever Design of their Labour Market Reforms? IZA Discussion Paper, (147), 2000.

[11] O. Blanchard and J. Wolfers. The Role of Shocks and Institutions in the Rise of European Unemployment: the Aggregate Evidence. The Economic Journal, (462), 2000.

[12] D. Blanchflower and A. Oswald. The wage curve. Scandinavian Journal of Economics, 92:215-35, 1990.

[13] D. Blanchflower and A. Oswald. The wage curve. MIT Press, 1994.

[14] T. Boeri, A. Brugiavini, and L. Calmfors. The Role of Unions in the Twenty-first Century - A Report for the Fondazione Rodolfo Debenedetti. Oxford University Press, Oxford, 2001.

[15] A.L. Booth, M. Francesconi, and G. Zoega. Training, rent-sharing and unions. Working Paper of the Institute for Labour Reseach, Colchester, University of Essex, (99/33), 1999.

[16] CEP. The CEP-OECD Data Set .

[17] W.W. Daniel and E. Stilgoe. The Impact of Employment Protection Laws. Policy Studies Institute, London, 1978. 
[18] F. Daveri and G. Tabellini. Unemployment, growth and taxation in industrial countries. Economic Policy, 30:47-104, 2000.

[19] D. Dickey and W. Fuller. Distribution of the estimators for autoregressive time series with a unit root. Journal of the American Statistical Association, 74, 1979.

[20] B. Ebbinghaus and J. Visser. Trade unions in western Europe since 1945. Macmillan, 2000.

[21] J. Elmeskov, J.P. Martin, and S. Scarpetta. Key Lessons for Labour Market Reforms: Evidence from OECD Countries' Experiences. Swedish Economic Policy Review, 5(2):205-52, Autumn 1998.

[22] S. Evans, J. Goodman, and L. Hargreaves. Unfair Dismissal Law and Employment Practice in the 1980s. Research Paper 53. London: Department of Employment, (53), 1985.

[23] R.A. Fisher. Statistical Methods for Research Workers. Oliver and Boyd, Edinbourgh, 4th edition.

[24] S. Galiani. Wage determination in Argentina: An econometric analysis with methodology discussion. University of Oxford, mimeo.

[25] J.A. Hausman. Specification tests in econometrics. Econometrica, 46:1251-1272, 1978.

[26] E. Huber, C. Ragin, and J.D. Stephens. Comparative Welfare States Data Set. Northwestern University and University of North Carolina, 1997.

[27] ILO. World Labour Report 1997-98. Industrial Relations, Democracy and Social Stability. Geneva, 1997.

[28] R. A. Judson and A.L. Owen. Estimating dynamic panel data models: a guide for macroeconomists. Economic Letters, 65:9-15, 1999.

[29] R. Layard, S.J. Nickell, and R. Jackman. Unemployment: macroeconomic performance and the labour market. Oxford University Press, 1991.

[30] E. Lazear. Job Security Provision and Employment. Quarterly Journal of Economics, 1990.

[31] A. Levin and C-F. Lin. Unit Root Test in Panel Data: New Results. Discussion Paper, UCSD, (93-56), 1993.

[32] J.G. MacKinnon. Model Specification Tests and Artificial regressions. Journal of Economic Literature, 30:102-146, 1992.

[33] G.S. Maddala and S. Wu. A comparative study of unit root tests with panel data and a new simple test. Oxford Bulletin of Economics and Statistics, Special Issue, pages 631-652, 1999. 
[34] M. McElroy. Weaker MSE criteria and tests for linear restrictions in regression models with non-spherical disturbances. Journal of Econometrics, 6, 1977.

[35] A. Newell and J. Symons. Wages and unemployment in OECD countries. London School of Economics Centre for Labour Economics, Discussion paper, (1038), 1993.

[36] S. J. Nickell. Unemployment: Questions and some answers. The Economic Journal, 108(448):802-816, 1998.

[37] S.J. Nickell. Biases in Dynamic Models with Fixed Effects. Econometrica, 49(6):1417-1426, November 1981.

[38] S.J. Nickell. Unemployment and Labor Market Rigidities: Europe versus North America. Journal of Economic Perspectives, (3):55-73, 1997.

[39] S.J. Nickell and L. Nunziata. Labour Market Institutions Database. CEP, LSE, September 2001.

[40] S.J. Nickell, L. Nunziata, W. Ochel, and G. Quintini. The Beveridge Curve, Unemployment and Wages in the OECD. CEP Discussion Paper (502), July 2001, forthcoming in M. Woodford (ed.) "Knowledge, Information and Expectations in Modern Macroeconomics: Papers in Honor of Edmund S. Phelps", Princeton University Press, 2002.

[41] S.J. Nickell, L. Nunziata, W. Ochel, and G. Quintini. Unemployment in Europe. 2001, forthcoming.

[42] S.J. Nickell and R. Layard R. Labour Market Institutions and Economic Performance. in Ashenfelter and Layard eds, Handbook of Labor Economics, North-Holland Press, III, 1999.

[43] L. Nunziata. The Evolution of OECD Labour Markets: 1960-1995. Nuffield College, Oxford.

[44] L. Nunziata. Institutions and Wage Determination: a Multi-Country Approach. Nuffield College Working Papers in Economics, (2001-W29), December 2001.

[45] OECD. Business Sector Database. Paris.

[46] OECD. Economic Outlook Database. Paris.

[47] OECD. Employment Outlook. Paris, 1994.

[48] OECD. Jobs Study: Evidence and Explanations. Paris, 1994.

[49] OECD. Employment Outlook. Paris, 1999.

[50] OECD. Employment Outlook. Paris, 2000.

[51] Danish Ministry of Finance. The Danish Economy: Medium Term Economic Survey. Ministry of Finance, Copenhagen, 1999. 
[52] A. Oswald. A Conjecture on the Explanation for High Unemployment in the Industrialised Nations. Warwick Economic Research Papers, 475, 1996.

[53] H. Pesaran and R. Smith. Estimating long-run relationships from dynamic heterogeneous panels. Journal of Econometrics, 68, 1995.

[54] E.S. Phelps. Structural Slumps, The Modern Equilibrium Theory of Unemployment, Interest and Assets. Harvard University Press, Cambridge MA, 1994.

[55] S. Roy. Some Aspects of Multivariate Analysis. Wiley, 1957.

[56] F. Traxler. Collective Bargaining and Industrial Change: A Case of Disorganization? A Comparative Analysis of Eighteen OECD Countries. European Sociological Review, 3(12), 1996.

[57] F. Traxler and B. Kittel. The Bargaining System and Performance: A Comparison of 18 OECD Countries. Comparative Political Studies (forthcoming), 33(9):1154-1190, 2000 .

[58] J. Visser. Unionisation Trends. The OECD Countries Union Membership File. University of Amsterdam, Centre for Research of European Societies and Labour Relations, 1996.

[59] M. Wallerstein. Wage-Setting Institutions and Pay Inequality in Advanced Industrial Society. American Journal of Political Science, 3(43), 1999.

[60] J.P. Windmuller. Collective Bargaining in Market Economies. A Reappraisal. Geneva: ILO, 1987.

[61] A. Zellner. An efficient method of estimating seemingly unrelated regression and tests for aggregation bias. Journal of the American Statistical Association, 57, 1962. 


\section{Data Appendix}

\section{A Countries and Time Period}

The data contain information about the evolution of labour market institutions in twenty OECD countries from 1960 to 1994.

The countries in the sample are:

$\begin{array}{llll}\text { Australia } & \text { Finland } & \text { Japan } & \text { Spain } \\ \text { Austria } & \text { France } & \text { Netherlands } & \text { Sweden } \\ \text { Belgium } & \text { Germany } & \text { Norway } & \text { Switzerland } \\ \text { Canada } & \text { Ireland } & \text { New Zealand } & \text { United Kingdom } \\ \text { Denmark } & \text { Italy } & \text { Portugal } & \text { United States }\end{array}$

Where possible, the data refer to West Germany throughout.

\section{B Definitions and Sources}

\section{B.1 Labour Market Institutions}

\section{EP: Employment Protection}

Blanchard and Wolfers (2000) provide an employment protection time varying variable from 1960 to 1995, each observation taken every 5 years. This series was built chaining OECD data with data from Lazear (1990). Notice that the OECD data, used from 1985 onward, is constructed on the basis of a more extensive collection of employment protection dimensions, compared with data used by Lazear. This dataset includes an interpolation of the Blanchard and Wolfers series, readjusted in mean. Range is $\{0,2\}$ increasing with strictness of employment protection.

\section{UDNET: Net Union Density}

For non-European countries this variable is constructed as the ratio of Total Reported Union Members (gross minus retired and unemployed members), from Visser (1996), to Wage and Salaried Employees, from Huber et al. (1997). The data are updated respectively from Bureau of Labor Statistics (United States: 1994 and 1995), from ILO (1997)[27] (Australia: 1995; New Zealand: 1994 and 1995; Canada: 1994 and 1995) and from the Basic Survey on Labour Unions by the Japan Ministry of Health, Labour and Welfare (Japan: 1995).

The data for European countries except Sweden are produced by Ebbinghaus and Visser (2000) using the same criteria. For what concerns Sweden, Ebbinghaus and Visser provide data on gross density only. Therefore we use the same sources we use for nonEuropean countries, updating the series using the growth rate of gross density in 1995 .

Note that: 
1. From 1991 onward the density data refers to unified Germany. To make the series consistent it was chained with the data provided by OECD and Bain and Price (1980);

2. New Zealand data on salary and wage earners is not available for 1962-1978 and 1982-1985 periods, so Net Union Density was calculated using Total Civilian Employment as denominator from the same dataset. In addition, an interpolation was used for missing New Zealand data in 1987-1988.

3. The data from Ebbinghaus and Visser do not include information for Portugal over the whole period and for Spain before 1982. An interpolation of OECD values was used for these observations, chaining the data when necessary.

\section{CO: Bargaining Coordination 1}

This is an index with range $\{1,3\}$ constructed as an interpolation of OECD data on bargaining coordination. It is increasing in the degree of coordination in the bargaining process on the employers' as well as on the unions' side. The resulting series were matched with the data provided by Belot and Van Ours (2000).

\section{COW: Bargaining Coordination 2}

Nickell et al. (2001) provide a coordination series constructed using similar criteria as above, but containing short term variation in coordination. Based on data reported in OECD Employment Outlook (1994) (1997), Traxler and Kittel (2000), Wallerstein (1999), Windmuller et al. (1987), Bamber and Lansbury (1998). For full details, see Ochel (2000).

\section{COIT1-COIT6: Coordination Types}

Dummy variables accounting for types of coordination based on a taxonomy due to Traxler (1996), Traxler and Kittel (2000).

Adopting Traxler taxonomy we have:

COIT1 $=$ inter associational coordination;

COIT2 $=$ intra associational coordination;

COIT3=pattern setting;

COIT4=state imposed coordination;

COIT5 $=$ uncoordinated;

COIT6 $=$ state sponsored coordination.

\section{BRR: Benefit Replacement Ratios}


Benefit Replacement Ratios data is provided by OECD with one observation every two years for each country in the sample. The data refers to first year of unemployment benefits, averaged over family types of recipients, since in many countries benefits are distributed according to family composition. The benefits are a proportion of average earnings before tax.

\section{BD: Benefit Durations}

An index was constructed by the authors as a weighted average equal to:

$B D=\alpha \frac{B R R_{2}}{B R R_{1}}+(1-\alpha) \frac{B R R_{4}}{B R R_{1}}$

where: $B R R_{1}$ is the unemployment benefit replacement rate received during the first year of unemployment, $B R R_{2}$ is the replacement rate received during the second and third year of unemployment and $B R R_{4}$ is the replacement rate received during the fourth and fifth year of unemployment. Note that we give more weight to the first ratio than to the second $(\alpha=0.6)$. If benefit provision stops after one year (min duration), then $B R R_{2}=B R R_{4}=0$, and $B D A V=0$. If however benefit provision is constant over the unemployment years, we have $B R R_{2}=B R R_{4}=B R R_{1}$, with $B D A V=1$.

\section{TW: Tax Wedge}

The tax wedge is equal to the sum of the employment tax rate, the direct tax rate and the indirect tax rate:

$$
T W=t 1+t 2+t 3 .
$$

The employment tax rate $t 1$ is calculated as

$$
t 1=\frac{E C}{(I E-E C)}
$$

with $E C$ equal to employers' total contributions and $I E$ equal to wages, salaries and social security contributions.

The direct tax rate $t 2$ is equal to

$$
t 2_{t}=\frac{D T_{t}}{H C R_{t}}
$$

where $D T$ is the amount of direct taxes and $H C R$ is the amount of households' current receipts.

The indirect tax rate is

$$
t 3_{t}=\frac{T X_{t}-S B_{t}}{C C_{t}}
$$

with $T X$ being total indirect taxes, $S B$ subsidies, and $C C$ private final expenditures.

All data come from London School of Economics CEP - OECD database, updated by authors using the same criteria. Generally, the data are taken from OECD National Accounts. 


\section{HO: Housing (proportion owner occupied)}

The data about owner occupier households, as percentage of total households, is provided by Oswald (1996). This data was recently updated by Oswald, so that the 1990 figure for Spain is $78 \%$ not $75 \%$, and the 1960 figure is $51 \%$ not $52 \%$, and the 1990 figure for Ireland is $78 \%$ not $81 \%$. Oswald data contain information about 19 countries (Portugal excluded) over 4 periods (1960, 1970, 1980 and 1990). This dataset contains an interpolation of Oswald's data.

\section{B.2 Macroeconomic Variables}

\section{UR: Unemployment Rate}

Standardized unemployment rate from Layard et al. (1991), updated by authors using the same criteria (see OECD Employment Outlook, 2000, Table A). The missing observations for Portugal are from CEP - OECD database. Data for Italy are based on the US Bureau of Labor Statistics, "unemployment rates on US concepts".

\section{LABC: Labour Cost}

Labour cost is defined as

$$
w-p=\log (I E)-\log (E T)-\log \left(P_{G D P}\right)
$$

where $I E$ are compensations of employees by resident producers, namely wages, salaries and social security contributions, ET is total employment and $P_{G D P}$ is GDP deflator at factor cost. All data is from CEP - OECD database, updated by authors using the same criteria, except for $P_{G D P}$ that is calculated from GDP at factor cost, current and constant prices, from OECD Business Sector Database.

\section{EPOP: Employment Population Ratio}

Total civilian employment normalised on the working age population (15-64), from CEP OECD data, updated by authors.

\section{RIRL: Real Interest Rate}

Long term real interest rate, constructed using long term nominal interest rate and inflation from OECD Economic Outlook Database.

\section{PRODHP: Trend Productivity}


The labour productivity measure, $\pi$ in the paper, was calculated as an Hodrick Prescott trend of log real GDP minus log of total employment, i.e.

$$
P R O D H P=\operatorname{HPtrend}\{\log (Y Q)-\log (E T)\}
$$

where $E T$ is total employment, and $Y Q$ is real GDP at 1990 prices.

\section{D2MS: Acceleration in Money Supply}

This is equal to $\Delta^{2} \ln (M S)$, where $M S$ is money supply from OECD Economic Outlook Database.

\section{LDS: Labour Demand Shock}

This series consists of the residuals $\hat{\varepsilon}_{t}$ of the following 20 by country regressions:

$\log \left(E T_{t}\right)=\beta_{0}+\beta_{1} \log \left(E T_{t-1}\right)+\beta_{2} \log \left(E T_{t-2}\right)+\beta_{3} \log \left(E T_{t-3}\right)+\beta_{4} \log \left(Y Q_{t}\right)+\beta_{5} \log \left(W T P_{t}\right)+\varepsilon_{t}$

where $E T$ is total employment and $Y Q$ and $W T P$ are respectively real GDP and real labour cost at 1990 prices.

\section{TTS: Terms of Trade Shock}

This series is equal to

$$
I M P=\frac{M C}{Y C} \Delta\left\{\log \left(\frac{P_{m}}{P_{G}}\right)\right\}
$$

where $M C$ are imports at current prices, $Y C$ is GDP at current prices, $P_{m}$ is import price deflator and $P_{G}$ is GDP deflator at market prices, both with 1990 as base year. The dataset contains also a factor cost version of the shock (TTSFC), calculated using the series on GDP deflator at factor cost.

\section{D2TFP: acceleration in TFP}

This series is calculated as a three years moving average of $\Delta^{2} T F P$, where TFP is the series from Nickell and Nunziata (2000). This is based on the Solow residual for each country.

\section{TFPHPC: HP cyclical component of TFP}

This series consists of the Hodrick Prescott cyclical component of the Solow residual,

$$
\text { TFPCY }=\text { Solow residual - HP trend . }
$$

